\title{
Ayak başparmağının hastalıkları: Halluks valgus ve halluks rigidus
}

\section{Diseases of the great toe: Hallux valgus and hallux rigidus}

\author{
Önder Kılıçoğlu \\ İstanbul Tıp Fakültesi Ortopedi ve Travmatoloji Anabilim Dalı, İstanbul
}

\begin{abstract}
Ayak anatomisi, yüklenme mekanikleri ve hastalıkları ile vücudun diğer bölgelerinden daha karmaşık bir uzvumuzdur. Başparmak ise ayağın hem yeterince hareketli, hem de yere transfer edilen kuvvetin zaman zaman \%90'ına kadar olan bir kısmını yüklenen özelleşmiş bir kısmıdır. Başparmağın her türlü hastalığı günlük yaşam kalitesinde ciddi bozukluğa yol açabilir.

Başparmağın en sık görülen iki sorunu, halluks valgus (HV) ve halluks rigidus (HR) birbirlerine oldukça zıt karakterde iki hastalıktır. En belirgin farklılık HV'un ayakkabı ile dolaşırken, HR'un ise ayakkabısız yürürken daha fazla ağrı yapmasıdır. Genç yaşta ikisi hemen hiçbir zaman birlikte bulunmaz. HV etiyolojisinde çok sayıda neden bilinirken, HR için travma dışında hiçbir elle tutulur neden yoktur. $H V$ hastası günlük yaşamını bir şekilde idame ettirirken HR hastası ağrıları nedeni ile daha hızlı bir tedavi peşinde koşar. HV hastasında deformitenin şiddetini belirlemek kolay, HR'de artrozun şiddetini belirlemek zordur.
\end{abstract}

HV cerrahi tedavisinde iki temel ardışık hedef vardır: Birinci basamakta parmak metatars başının üzerinde, metatars ile aynı eksene getirilir. Íkinci basamakta ise aralıklı duran metatarslar yaklaştırılır. İkinci basamak için çok farklı seviyelerden çok farklı osteotomi teknikleri bildirilmiştir. Makalede bu seçenekler arasından doğru olanı seçebilmek için önemli ipuçları sunulmuştur. HR tedavisinde ise tedavi seçiminde en önemli ve zor basamak artrozun düzeyini doğru belirlemektir. Cerrahi tedavi seçimi artroz düzeyine göre yapılır. Artrozun yanlış değerlendirilmesi durumunda, özellikle basit cerrahiler uygulanan hastalarda yüksek memnuniyetsizlik oranları ile karşılaşılmaktadır.

Anahtar sözcükler: ayak parmakları; halluks valgus; halluks rigidus; metatarsallar; osteotomi
Compared to other areas of the body, the foot is a more complex structure in terms of its anatomy, loading mechanics and diseases. The great toe is a specialized part of the foot, which is sufficiently mobile and also strong enough to support almost $90 \%$ of the weight transferred to the ground. Diseases involving the great toe may cause significant impairment in quality of daily life.

The most frequent diseases of the great toe are hallux valgus (HV) and hallux rigidus (HR), which are contradictory conditions. Most prominent difference is that HV causes pain within the shoe while HR is more painful barefoot. In young patients, they never exist simultaneously. HV is caused by many etiological factors, but HR does not have a defined etiology other than trauma. HV patients may continue their daily activities, but HR patients seek immediate remedy because of pain. Severity of the deformity may be determined easily in HV, but it is difficult to identify the severity of osteoarthritis in HR.

There are two basic and consecutive aims in the surgical treatment of HV. At the first stage, the great toe is brought to the same axis with the first metatarsal. At the second stage, the first and second metatarsals are brought closer together. Various osteotomies at various levels have been suggested for the second stage. Tips and tricks for choosing among these options are presented in this article. The major and most difficult aspect of the treatment of HR consists of identifying the stage of osteoarthritis, which determines the type of surgery. Mistakes made in this evaluation are met with high patient dissatisfaction.

Key words: toes; hallux valgus; hallux rigidus; metatarsals; osteotomy

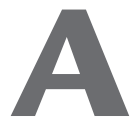

yak başparmağı diğer parmaklardan daha farklı, özel bir bölgedir. Diğer parmaklarda üç falanks bulunurken başparmağın iki falanksı olduğu kabul edilir. Birinci metatarsın fizinin diğer metatarsların aksine, distalde değil proksimalde yer aldığını dikkate alırsak, aslında birinci parmağın metatarsının olmadığı, ya da belki de mediyal kuneiforma dönüşmüş olabileceği gerçeği ile karşılaşırız. Başparmak ayağın topuktan sonra en çok yüklenen bölgesidir, hızlı ilerleme, zıplama sırasında yüksek yüklere maruz kalır, vücut ağırlığının \%90'ı başparmaktan geçer. Bu nedenle başparmak hastalıkları hastalar için rahatsız edici, önemli

- İletişim adresi: Prof. Dr. Önder Kılıçoğlu, İstanbul Tıp Fakültesi Ortopedi ve Travmatoloji Anabilim Dalı, Millet Cad. 118 , 34093 Fatih, İstanbul Tel: 0212 - 41420 00/31514 e-posta: kilicoglu@istanbul.edu.tr

- Geliș tarihi: 27 Eylül $2013 \quad$ Kabul tarihi: 24 Ekim 2013 
fonksiyon kaybına yol açan sorunlardır. Bu sorunlar arasından en sık görülen ikisi, halluks valgus (HV) ve halluks rigidus (HR) bu makalede ele alınacaktır.

\section{HALLUKS VALGUS}

HV baş parmağın ekseninin birinci metatarsın eksenine göre dış yana doğru olan açılanmasının artışını tarif eden klinik bir tanıdır. "Bunion" terimi sıklıkla aynı anlamda kullanılsa da birinci metatars başının mediyalinde oluşan ağrılı şişliği tanımlamak için tercih edilmelidir. Her HV olgusunda bunion bulunmayabilir. Podiatri ekolü ise klasik HV olgularında intermetatarsal açının hemen her zaman artmış olmasına dayanarak "metatarsus primus varus" terimini tercih etmektedir.

Klinikte karşılaştı̆ıımı HV olguları etiyolojileri, ortaya çıkış zamanları, evreleri ve hastanın genel tıbbi durumu açısından birçok farklılıklar gösterir. Parmaktaki deformitenin şiddeti de her zaman klinik yakınma düzeyi ile ilişkili değildir. Bu farklılıklar nedeni ile tüm olgularda uygulanabilecek standart bir cerrahi tedavi girişim bulunmamakta, kaynak kitaplarda birbirinin alternatifi olarak sunulan çok sayıda girişim tanımlanmaktadır. Ortopedistler tarafindan yaygın olarak dile getirilen " 150 farklı HV cerrahi tekniği vardır” iddiası Kelikian'ın 1965'te yayınladığı ve o güne kadar tanımlanmış yaklaşık 150 cerrahi tekniği derlediği monografiye dayanmaktadır. ${ }^{[1]}$ Aslında, tüm bu teknikleri az sayıda grup içinde sınıflamamız mümkündür. Bu sayede farklı tipteki deformiteler için farklı gruplardan birer cerrahi tekniğin seçilmesi yeterli olacaktır.

Bu derlemenin amacı HV deformitesinin değerlendirmesinde kullanılacak temel kriterleri tanıtmak ve tedavi seçiminde yardımcı olacak basit bir algoritma sunmaktır.

\section{Standart radyografik değerlendirme}

Tüm ayak sorunlarında olduğu gibi, HV deformitesinin radyografik değerlendirmesinde de basarak çekilen anterior-posterior (AP) (Şekil 1a) ve lateral (Şekil 1b) ayak grafileri temel tetkiklerdir. Bunlara ek olarak ayak bileğinin basarak AP grafisi ve sesamoid tangential grafiler de gerekli olabilir (Şekil 1c). Bu tetkiklerde deformitenin şiddetini gösterecek açı ölçümleri yanında ayağın genel durumu değerlendirilmeli, metatarsofalangeal
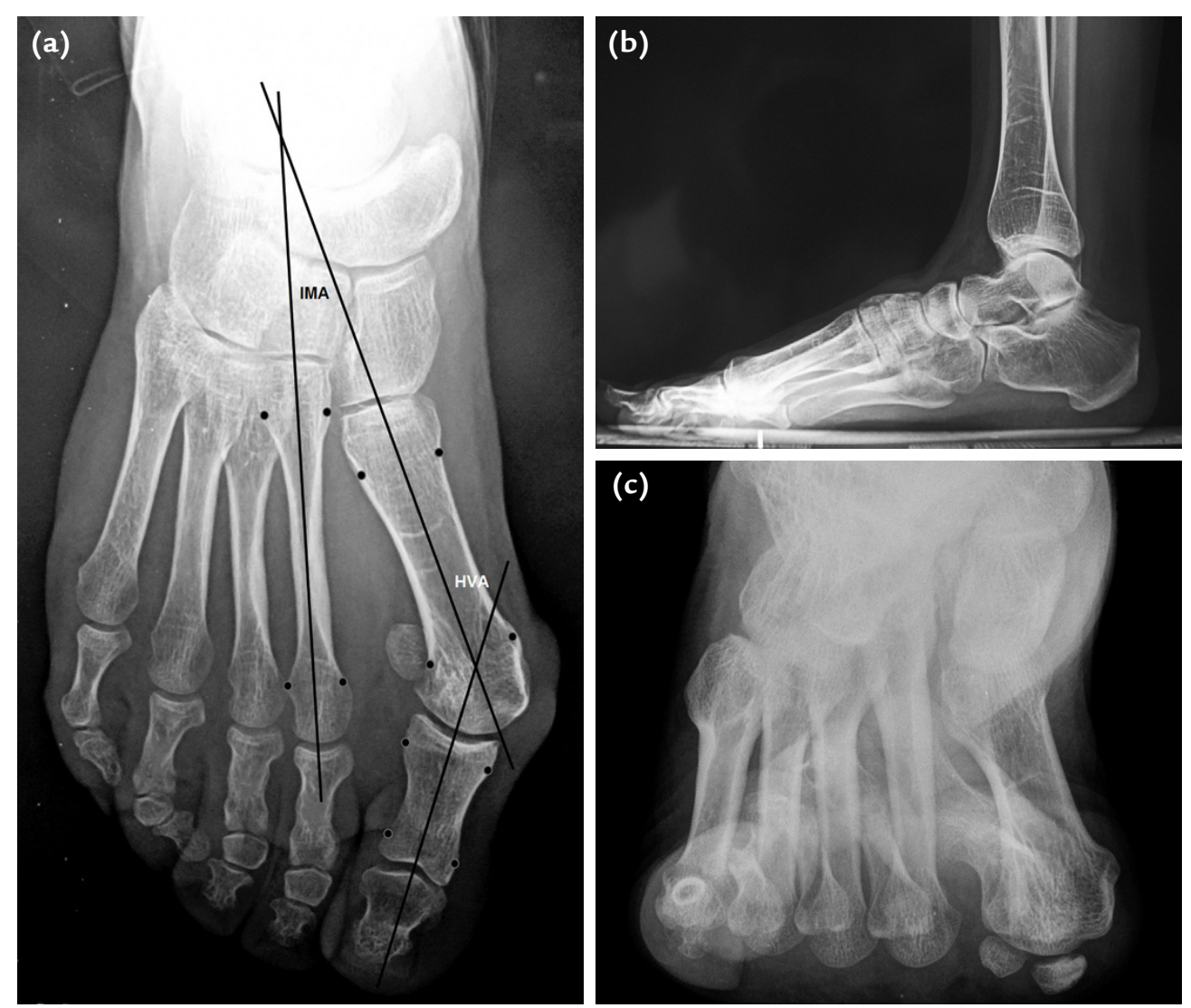

Şekil 1. a-c. HV değerlendirmesinde standart ayak grafileri. a) Basarak AP grafi. Diyafiz orta hattına göre IMA ve HVA ölçümü. b) Basarak lateral grafide tüm ayak görülebiliyor. c) Sesamoid tangential grafide sesamoidlerin metatarsın kristasına göre pozisyonunun değiştiği görülüyor. 
eklemde (MTF) veya komşu eklemlerde artroz varlığı da araştırılmalıdır.

Basarak AP grafide birinci ve ikinci metatarslar arası açı (IMA 1-2), başparmağın ekseninin birinci metatars ekseni ile yaptı̆̆ı açı (HV açısı [HVA]) (Şekil 1a) ve proksimal falanksın eklem yüzeyleri arasında oluşan açı (halluks interfalangeal açı [HIA]) (Şekil 2) ölçülür. Birinci metatarsın distal eklem yüzünün metatarsın ekseni ile ilişkisi de (distal metatarsal eklem yüzü açısı [DMAA]) tedavi seçimindeki önemli parametrelerden biridir (Şekil 2). Açıların ölçümünde iki temel yöntem vardır: ${ }^{[2,3]}$ Diyafiz eksenlerini temel alan yöntemde metatars diyafizinin distal ve proksimal ucundan $1 \mathrm{~cm}$, proksimal falanksın eklem yüzlerinden $0,5 \mathrm{~cm}$ geriden orta noktalar bulunarak birleştirilir. Metatars başının merkezini esas alan yöntemde ise diyafizin basisinin merkezi ile metatars başı birleştirilerek diyafiz ekseni belirlenir. Bazı yazarlara göre bu iki ölçüm arasında 9 dereceye ulaşan farklar bulunabilir. ${ }^{[2,3]}$ Diyafız eksenleri temel alınarak yapılan ölçümlerde IMA 1-2 için üst sınır 9 derece, HVA için normal değer 15 derecenin, HIA için 10 derecenin altı olarak kabul edilir. DMAA'nın normal sınırları 0-6 derece arasıdır. ${ }^{[4]}$

Eklem yüzleri arasındaki ilişki incelendiğinde falanksın laterale kayması nedeni ile eklemin sublukse olduğu, falanksın metatars başının lateral kenarına oturduğu, başın mediyaldeki büyük bir kısmının ise örtülmediği gözlenir. Bu tip bir ilişki "uyumsuz eklem" olarak isimlendirilir. Eklem uyumu HV'yi düzeltecek bir cerrahi tedavi planlamasında ilk dikkate alınacak parametredir.

Sesamoidlerin yer değiştirme miktarı bilimsel çalışmalarda sonuç değerlendirme ölçütü olarak kullanılmakla birlikte, tedavi seçim algoritmalarında pek yeri yoktur. Buna karşılık sesamoid artrozunun şiddeti klinik sonuç üzerinde çok önemli bir etmendir.

\section{$H V$ 'de radyografik evrelendirme}

HV için kullanılan sınıflamalar klasik olarak HV açısını ve intermetatarsal açıyı (IMA 1-2) esas alan evrelendirmelerdir. Öte yandan, bu evrelendirmelerde kesin kabul edilmiş eşik değerler bulunmamaktadır. Birçok yazar olgu serilerini sunarken veya kaleme aldıkları derlemelerde istatistiksel testlere dayanmayan farklı eşik değerler belirlemiş, tedavilerini bunlara dayanarak yönlendirmiştir. Hatta, ayak cerrahisinin duayenlerinden olan Roger Mann'ın belirlediği sınırlar oğlu Jeffrey Mann'ın sınırları ile dahi uyuşmamaktadır (Tablo 1). ${ }^{[5-7]}$

\section{HV'de etiyoloji ve etiyolojiye dayalı sınıflandırma}

Hem hastalar hem de hekimlerin büyük bir kısmı HV deformitesinin dar ve topuklu ayakkabı giyimine bağlı

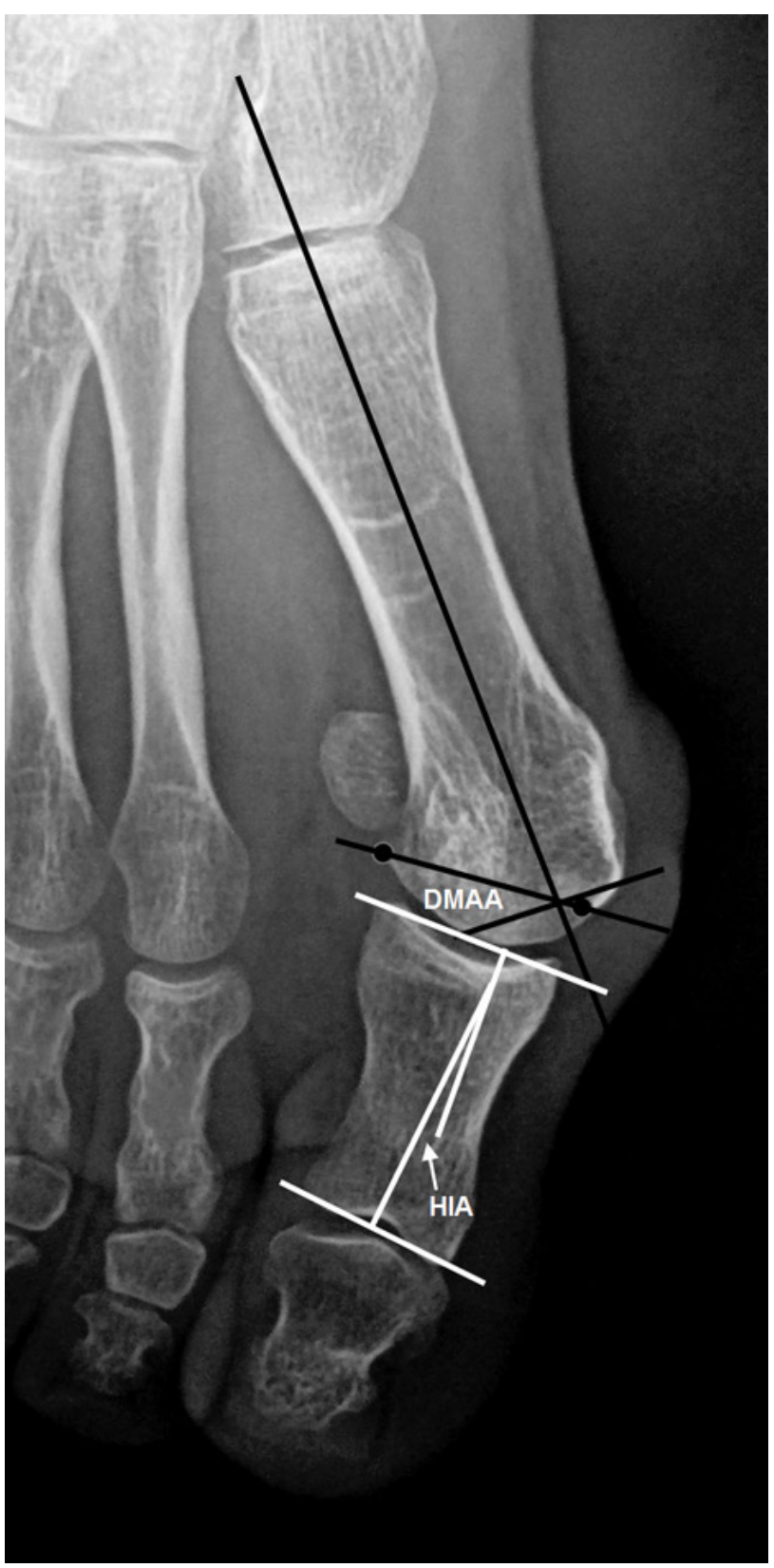

Şekil 2. AP grafide DMAA ve HIA ölçümü. Uyumlu olarak değerlendirilen MTF eklemde DMAA'nın normal sınırların çok üzerinde olduğu görülüyor.

olduğuna inanır. Ancak, değil tüm olguları, hemen hiçbir olguyu yalnızca bu neden ile açıklamak mümkün değildir. Hiç ayakkabı giymeyen halklarda dahi bu deformite gözlenebilmektedir.

HV'nin yalnızca bir deformite isimlendirmesi olduğunu ve birçok nedene bağlı olarak ortaya çıktığını biliyoruz. Bu nedenle, öncelikle eşlik eden diğer sorunlar, deformitenin seyri ve hatta hastanın soy geçmişi dikkate alınarak etiyolojiye dayanan bir tiplendirme 
yapılmalıdır. Daha sonra da açısal kriterlere göre bir evrelendirme eklenebilir.

\section{A. Klasik HV}

En sık karşılaştığımız tip klasik tip HV'dir. Metatars başlarının kavisinin yayılması, IMA 1-2'lerin tümünün artması ve mediyal-lateral genişliğin artması ile karakterizedir. Birinci metatars başı mediyale giderken parmaklar birbirlerine göre pozisyonlarını korumuşlardır. Bu durumda sorun esas baş parmağın dışa açılanması gibi gözükse de aslında metatars başının mediyale kaymasıdır (metatarsus primus varus). Ağrılı bunion en belirgin bulgudur. Klasik bir HV olgusunda bunion yeni bir kemik oluşumu değildir, mediyale açılanan metatarsın başının belirginleşmesinin bir sonucudur. Ayağın yayılması nedeni ile ayrıca 2. parmakta MTF eklem sorunları, 3-4 metatars başları arasında Morton nöroması ve 5. metatars başının dış yanında mediyaldeki buniona benzer bir çıkıntı (bunionet) oluşabilir. Bu dört bulgu "splay foot" olarak da isimlendirilen yayılmış ayağın bileşenleridir.

Radyolojik bulgular da tipiktir. DMAA normal sınırlardadır. IMA 1-2 artışı HVA artışı ile paralel seyreder, her ikisi de aynı oranda artmıştır. MTF eklem laterale subluksedir, deformite uyumsuz olarak adlandırılır. Radyografik evrelendirmeler bu tip HV'nin sınıflaması için geçerlidir.

\section{B. Adolesan ve juvenil HV}

Çocukluk çağında klinik bulgu veren tiptir. Tipik özelliği distal metatarsal eklem yüzünün laterale fazla açılanmasıdır (Şekil 2). Eklem sublukse değildir, yalnızca bu tip HV'de uyumlu bir eklem söz konusudur. HVA 1-2 yüksek ölçülürken HVA aynı oranda yüksek olmayabilir. ${ }^{[8,9]}$ Çocukluk çağında görülmesi her zaman deformitenin hızlı ilerleyeceğinin bir belirtisi değildir. MTF eklemde dejenerasyon gelişimi klasik tipe göre daha nadirdir. Erişkin yaşlara kadar açılarda artış olmadan ulaşılabilir. Bu nedenle, klinik yakınma yoksa erken cerrahi girişim endikasyonu bulunmamaktadır.

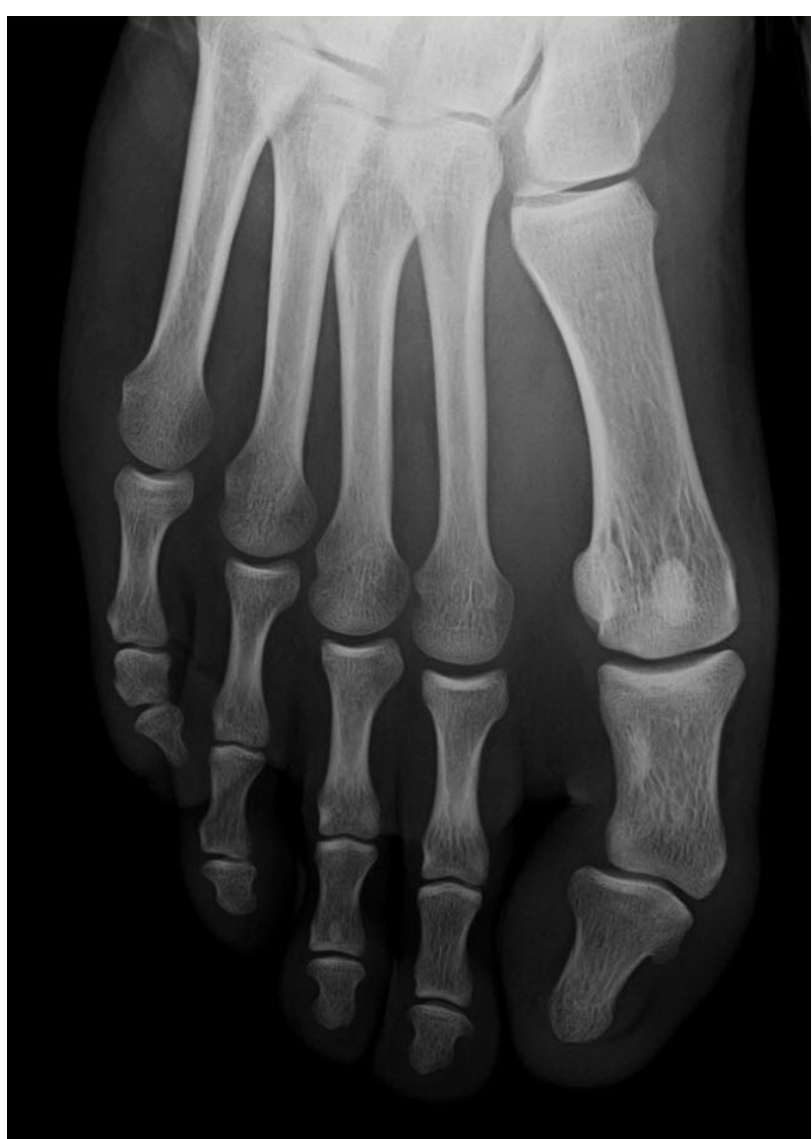

Şekil 3. Proksimal falankstan kaynaklanan bir HVI olgusu. Metatars başının düzlüğü dikkat çekici seviyede.

İleri yaşlarda cerrahi tedavi yüksek DMAA ve IMA nedeniyle teknik zorlukluklar içerebilir.

\section{Halluks valgus interfalangeus (HVI)}

Bu tipte klinikte gözlenen açılanmanın en azından bir kısmı falanksların eğriliğinden kaynaklanmaktadır (Şekil 3). Sıklıkla metatars başının yuvarlak değil düz şekilli olduğu görülür. Klinik görünüm tipik ve tanı koydurucudur. Radyografide proksimal falanksın

Tablo 1. Farklı HV evrelendirme tabloları

\begin{tabular}{|c|c|c|c|c|c|c|}
\hline & \multicolumn{2}{|c|}{ Roger Mann ${ }^{[5]}$} & \multicolumn{2}{|c|}{ Jeffrey Mann ${ }^{[6]}$} & \multicolumn{2}{|c|}{ Michael Coughlin ${ }^{[7]}$} \\
\hline & $\operatorname{HVA}\left({ }^{\circ}\right)$ & $\operatorname{IMA}\left({ }^{\circ}\right)$ & $\operatorname{HVA}\left({ }^{\circ}\right)$ & $\operatorname{IMA}\left({ }^{\circ}\right)$ & $\operatorname{HVA}\left({ }^{\circ}\right)$ & $\operatorname{IMA}\left({ }^{\circ}\right)$ \\
\hline Normal & & & 15 & 9 & & \\
\hline HafifHV & $<20$ & $8-16$ & $<30$ & $<13$ & $<20$ & $<11$ \\
\hline Orta HV & $21-40$ & $6-19$ & $30-40$ & $13-20$ & $21-40$ & $11-16$ \\
\hline Ileri HV & $>40$ & $11-20$ & $>40$ & $>20$ & $>40$ & $16-18$ \\
\hline
\end{tabular}


proksimal ve distal eklem yüzeyleri arasındaki açılanmanın artışı dikkat çeker. Altı derecenin üzerinde bir açı radyolojik kriter olarak kabul edilmektedir. Interfalangeal eğriliğin ön planda olduğu bir olguda klasik HV girişimleri yapıldığı takdirde arzu edilen sonuçlara ulaşmak mümkün olamamaktadır.

\section{Nöromusküler tip HV}

Başparmağın kasları arasındaki dengesizlik nedeniyle ortaya çıkar. İzole HV deformitesi daha çok spastik tipteki beyin felcinde görülür (Şekil 4). Bu tip bir deformitede HVA çok yüksek iken IMA 1-2 normal sınırlarda dahi olabilir. Eklem laterale subluksedir, uyumsuz tipte bir ilişki vardır. Meningomiyeloselde ise genellikle pes planus gibi başka deformitelerde eşlik eder.

\section{E. Ayak deformitelerine eşlik eden HV}

Ayağın arka kısmı veya ortasındaki deformiteler her zaman ayağın ön kısmını da etkilemektedir. Doğumsal veya edinsel pes planus'u veya başka bir deyişle hiperpronasyon ayağı bulunan hastalarda, hastanın ayak mediyaline bastığında baş parmağın valgusa gelerek ayağın kaldıraç kolunu kısaltmaktan başka bir çaresi kalmamaktadır. Bu tip HV'de başparmağın hiperpronasyonu da çok belirgindir. ${ }^{[10,11]}$ Basarak lateral grafide ayağın kavisindeki çökme ileri düzeydedir. Tam tersi bir deformitede, metatarsus adductus'ta ve kavus ayağında da metatarsların tümü mediyale açılanırken ayağın ayakkabıya girebilmesi için ön ucunun, yani baş parmağın valgusa açılanması şart olmaktadır.

Ayak deformitelerinin bir bileşeni olan HV olgularının radyolojik incelemesinde HVA 1-2'nin düşük hatta normal olduğu, HVA'nın yüksek olduğu görülür. En önemli ayırt ettirici bulgu 2. metatarsın ekseninin ayağın eksenine göre varusta olması, birinci metatars ile birlikte varusa gelmiş olmasıdır. Tüm ayağın ekseni düzeltilmedikçe HV eğriliğinin yeterince düzeltilmesi mümkün değildir.

\section{F. Doğumsal anomaliler ile ilişkili HV}

HV'ye doğrudan neden olabilen doğumsal anomaliler olabileceği gibi bazı anomalilerde sekonder olarak başparmak eğrilikleri ortaya çıkabilir. Intermetatarsal faset varlığı veya os intermetatarseum gibi doğumsal sorunlar HV ile doğrudan ilişkili olabilirler (Şekil 5). ${ }^{[12,13]}$ Ayrıca, ayağın birçok doğumsal anomalisinde başparmak ayakkabı giyimine bağlı olarak laterale açılanmak zorunda kalabilir.

\section{Klinik değerlendirme}

Klasik tipteki HV hastasının en belirgin iki yakınması başparmağın dışa doğru eğrilmesi ve iç yanda ağrılı bir

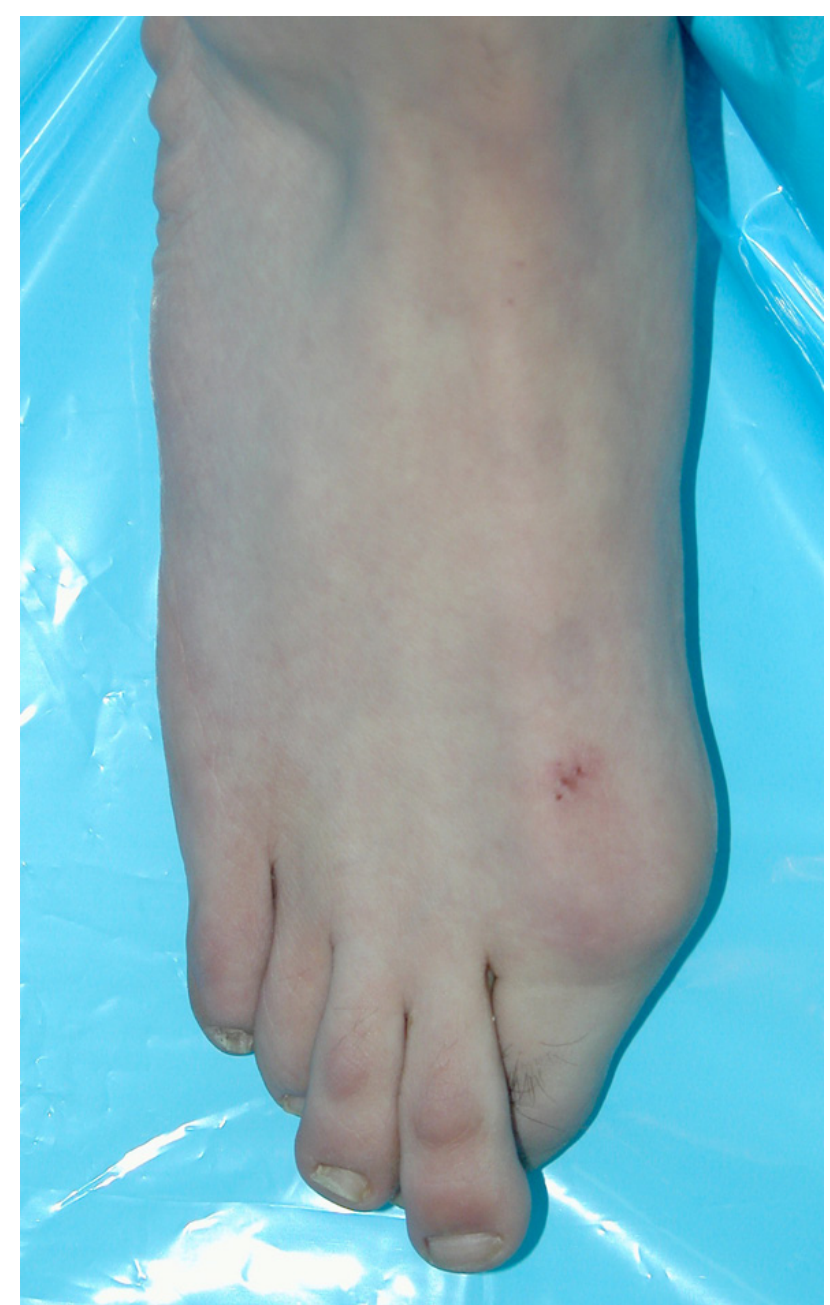

Şekil 4. Beyin felci olan, ergenlik çağındaki bir hastada gözlenen HV deformitesi. Yalnızca başparmağın dış yana açılandığı ve ileri deformiteye rağmen tipik bir bunion gözlenmediği dikkati çekiyor.

kemik çıkıntının (bunion) ortaya çıkmasıdır. Ayakkabı giyimi sırasında, bunion üzerinde şiddetli ağrı hissedilir, ayakkabısız iken yakınma yoktur. Eğer hasta ayakkabı giyerken ağrısının daha az olduğunu ifade ediyorsa birincil tanı HR'dir; HV yalnızca eşlik eden bir sorundur. Ayrıntılı olarak sorulduğunda hasta yalnızca dar veya topuklu ayakkabı giydiğinde sıkıntı çektiğini belirtebilir. İleri deformiteli olgularda bunion üzerinde ciltte eritem ve ülserasyon dahi oluşabilir. MTF eklemde ağıı yakınması da olabilir, ancak bu yakınma geri plandadır. Yakınma düzeyi deformitenin şiddeti ile orantılı değildir. ${ }^{[14]}$ Çok az sayıda hasta temel yakınmasının estetik sorun olduğunu belirtir.

Metatars kavisinin yayılması ile seyreden klasik HV'de 2. metatarsın başının altına uyan bölgede nasır oluşumu, çekiç parmak gelişimi, 5. metatars başının 


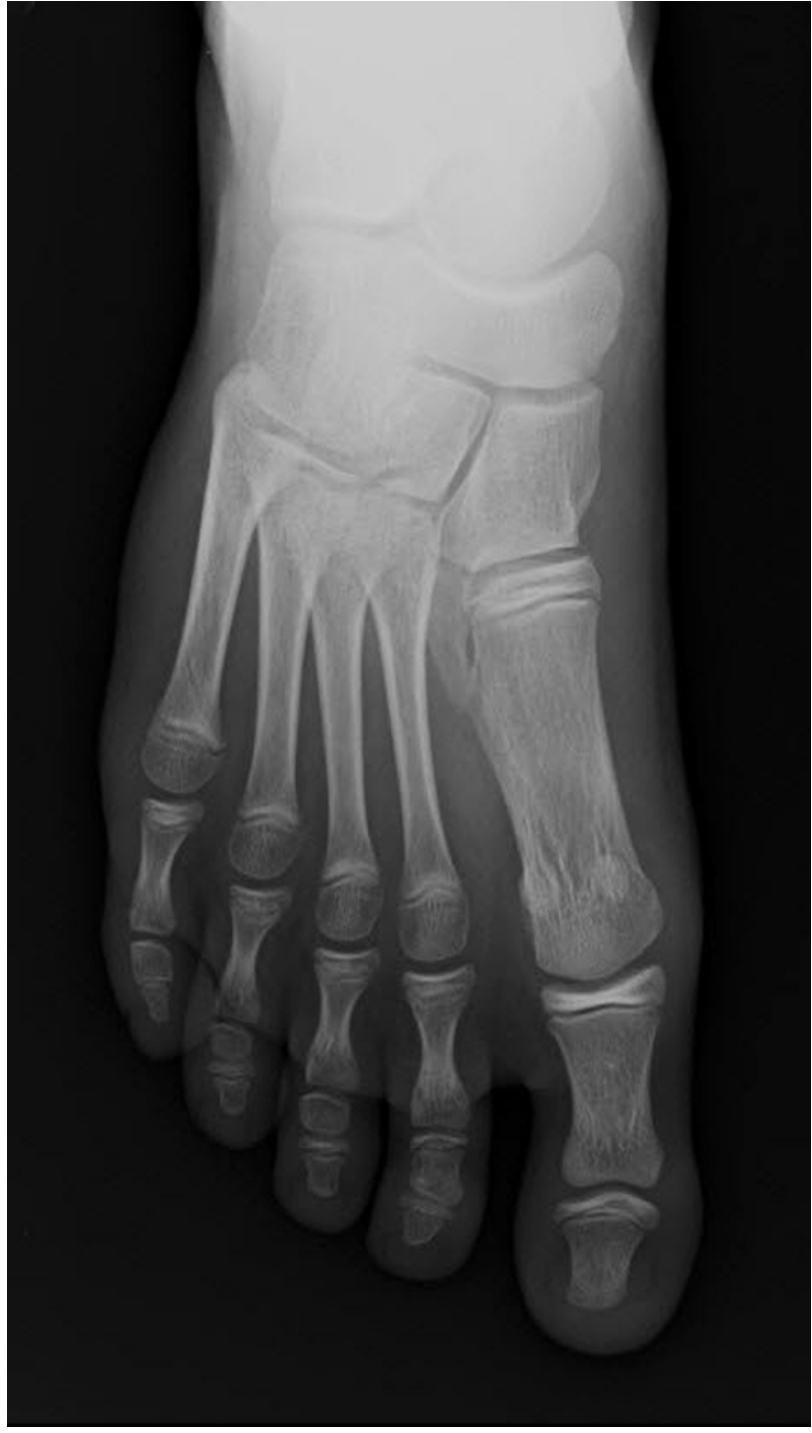

Şekil 5. Birinci ve ikinci metatars basisleri arasında aksesuar bir kemik olan os intermetatarseum'un HV'ye yol açabildiği olduğu kabul edilir.

dış yana açılanması, çıkıntılı ve hassas hale gelmesi (bunionet) ve Morton nöroması oluşumu da tablonun sık karşılaşılan bileşenleridir. Bu ek sorunlar ilk muayene sırasında muhakkak sorgulanmalıdır.

HV ön tanısı ile değerlendirilen bir hastada tibialis posterior tendon fonksiyonunun, Aşil tendonunun veya izole gastroknemius kasının gerginliğinin de değerlendirilmesi şarttır. Topukta veya orta ayaktaki fikse pronasyon-supinasyon veya ekinizm deformiteleri tedavi yaklaşımında önemli kriterlerdir. Ayakta duyu kaybı, iskemi varlığı araştırılmalıdır. Romatizmal hastalık öyküsü sorgulanmalı, yaygın eklem laksitesi aranmalıdır. Morton tarafından 1928'de önerilmiş bulunan metatarsokuneiform (MTK) eklemdeki instabilitenin
HV'ye yol açabileceği hipotezi ise henüz ispatlanamamıştır. ${ }^{[15]}$

MTF eklemin hareket açıklığı önemli bir muayene bulgusudur. İlk başvuru sırasında valgus açılanmasının pasif olarak ne kadar düzeltilebildiği ve sagittal plandaki hareketin açıklığı kaydedilmelidir. HV cerrahisi uygulanan olguların neredeyse tümünde sagittal hareketin bir miktar daha kısıtlanacağı unutulmamalı, hastaya bu konuda muayene sırasında bilgi verilmelidir.

\section{Tedavi}

HV hastaları tedaviden beklentilerini öncelikle rahat yürüyebilmek ve bunion üzerindeki acılarının geçmesi, ardından da günlük ayakkabıları rahat giyebilmek olarak dile getirirler. ${ }^{[16]}$ Kırk yaşın altında şık ayakkabıları giyebilmek beklentiler arasında ön sıralarda yer alırken kırk yaşın üzerinde günlük ayakkabıları rahat giyebilmek hedef haline gelir. Kadınlar yürüyüş yapabilmek için, erkekler ise daha rahat çalışabilmek için yardım istemektedir. ${ }^{[16]} \mathrm{HV}$ için tedavi arayan hastalar genel popülasyona göre hem daha sağlıklı, hem daha yüksek duygulanıma sahip, hem de mental açıdan daha iyi durumdadır. ${ }^{[14]}$ Hasta nasıl ifade ederse etsin, özellikle kadınlarda estetik kaygıların önemli bir neden olduğu hiçbir zaman göz ardı edilmemelidir.

\section{Konservatif tedavi}

HV hastalarının neredeyse tümü cerrahi dışı bir yöntem ile parmaklarının düzeltileceği beklentisine sahiptir. Gerçekten yakınması olan bir hastada cerrahi dışında bir tedavi yöntemi ile ayakkabı içindeki konforun arttırılması mümkün değildir. Öte yandan, geniş burunlu ve veya özel yapılmış ayakkabılar tercih edilirse hastanın yakınmalarının tümünün geçeceği ve bunun da konservatif bir yaklaşım olduğu cerrahlar tarafından hiçbir zaman unutulmamalıdır. Piyasada bu beklentiyi karşıladığı iddiası ile üç çeşit ortez satılmaktadır: gece atelleri, parmak arası makaraları ve bunion yastıkları (Şekil 6). Ne yazık ki bugüne kadar bu ortezlerin kalıcı bir yarar sağladığı gösterilememiştir. ${ }^{[17]}$ Bunion destekleri ve parmak arası makaraları ayakkabının burnunda ihtiyaç duyulan alanı arttıracağı için birçok hastada ayakkabı giyimini daha da güçleştirir. Hatta, juvenil HV olgularında bu ortezlerin deformiteyi arttırabildiği dahi iddia edilmiştir. ${ }^{[18]}$

\section{Cerrahi tedavi}

HV'de tedavinin hedefi ortaya çıkmış olan yakınmaların giderilmesidir. Yakınması olmayan bir hastada, ileride deformite artabileceği gerekçe gösterilerek cerrahi girişim önerilmesi uygun değildir. Tüm ayak girişimlerinden sonra ayakta hafif de olsa ağrı, şişlik ve hareket kısıtıılı̆ı gibi bazı yakınmaların kalacağı 

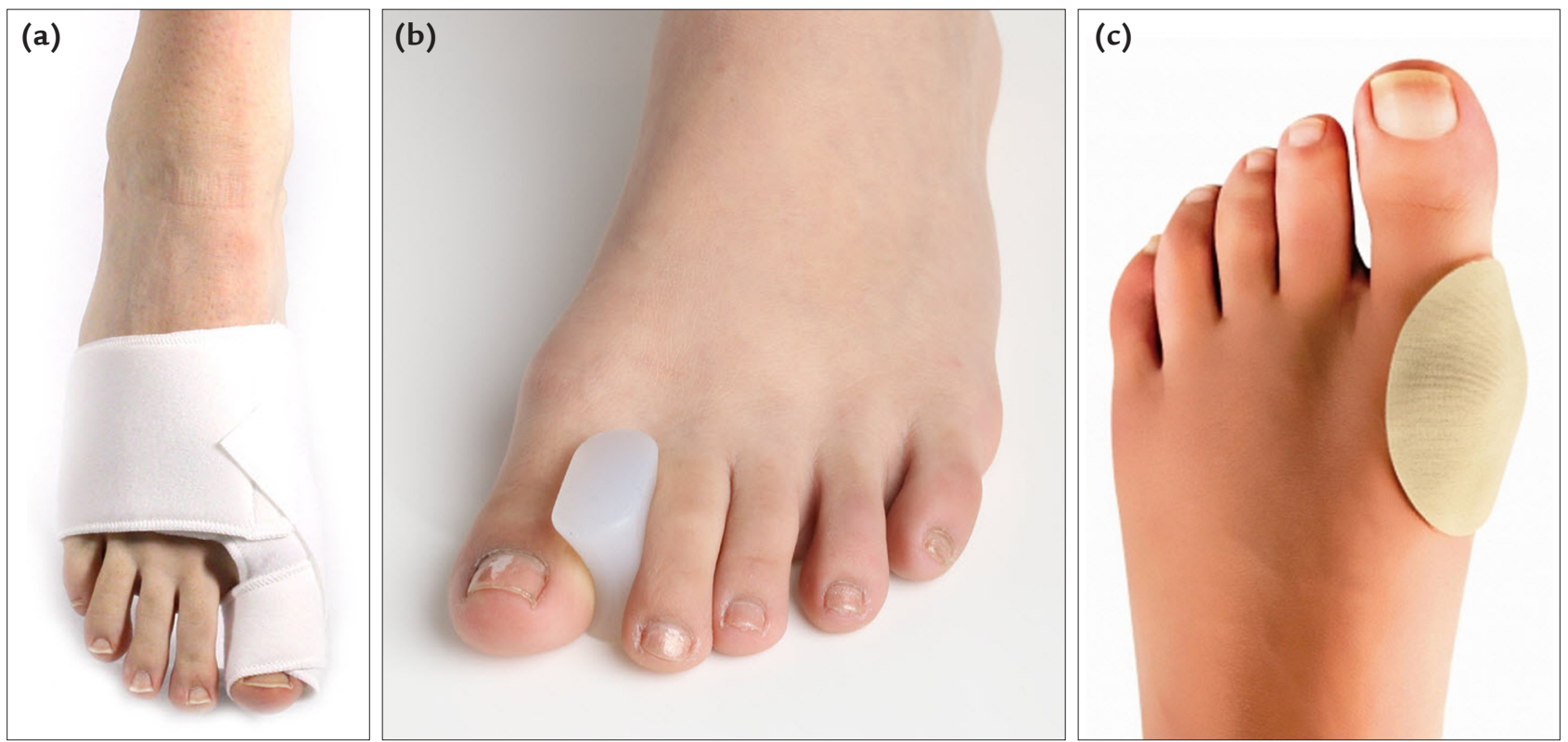

Şekil 6. a-c. a) HV gece ateli, b) parmak arası makarası ve c) bunion yastığı.

unutulmamalı, hiçbir ayak ameliyatı yalnızca estetik kaygılarla yapılmamalıdır. HV hastası ayakkabı giymediğinde bir yakınması yoktur. Tedavinin amacı hastanın piyasada hazır satılan, konfeksiyon ayakkabılar ile günlük yaşamında konforlu bir şekilde yürüyebilmesini sağlamak olmalıdır. Ameliyat sonrasında topuklu veya dar ayakkabı giymelerine sıcak bakılmadığı, hastalara tedavi öncesinde açıcça belirtilmelidir.

Ameliyatın zamanlaması da önemli bir ayrıntıdır. HV deformitesinin düzeltilmesi acil bir girişim değildir, yalnızca sürekli bası yarası açılması olasılığı bulunan hastalarda öncelik tanınabilir. Çekiç parmak deformitesinin düzeltilmesi gereken, bunion üzerinde bası yarası riski bulunan hastalar buna örnek olarak gösterilebilir. Bunun dışında kalan hastalara acil veya erken girişim önerilmesi gerekli değildir.

Sistemik hastalıklar da HV girişimi planlamasında dikkate alınmalıdır. İskemik bir ayakta klasik HV cerrahi yaklaşımı doğru değildir. Diyabete bağlı duyu kaybı, enfeksiyon gibi sorunlar ortaya çıkmış ise zorunlu olmayan tüm ayak girişimlerinden kaçınmak gereklidir. Zorunlu kalındığında ise olabildiğince az zarar verecek yöntemler tercih edilir. Örneğin diyabetik ayağı olan bir hastada 2. çekiç parmağı düzeltmek için başparmak eğriliğini düzeltmek yerine 2. parmağı ampute etmek çok daha koruyucu bir yaklaşımdır. ${ }^{[19]}$ Birinci MTF eklemin romatizmal tutulumuna bağlı bir deformitenin klasik teknikler ile tedavi edilmesi ise sıklıkla nüks ve hatta ağrılı bir eklem ile sonuçlanır. Bu hastalarda artrodez ön planda tercih edilecek seçenek olmalıdır.
MTF eklemde veya sesamoid eklemde artroz ileri evreye ulaşmış hastalarda da deformitenin düzeltilmesi yerine MTF artrodez tercih edilmelidir.

\section{Cerrahi tedavi algoritması}

Cerrahi tedavi planlamasının ilk aşamasında deformitenin tipi (etiyolojisi) belirlenmelidir. Kaynak kitaplarda karşılaştığımız algoritmalar genellikle klasik tipteki, yani yüksek HVA ve yüksek IMA 1-2 ile seyreden olgular için hazırlanmıştır. Klasik tip dışındaki olgularda hastaya özel bir tedavi gerekir. Örneğin HVI tipindeki bir deformitede yalnızca proksimal falanksın basisinden yapılacak bir ostetomi ile (Akin osteotomisi) yeterli düzeltme sağlanabilir. Nöromusküler tipteki bir deformitede ise yalnızca distal yumuşak doku dengelemesi ile başarılı sonuç elde edilebilir. Romatizmal tipte artrodezler, konjenital tipte ise standart dışı girişimler gerekli olacaktır.

Klasik tipteki, yayılmış ayağın bir bileşeni olan HV deformitesinin tedavi planlamasını iki basamaklı basit bir algoritma ile özetlemek mümkündür (Şekil 7). Bu basamaklarda tercih edilecek girişimleri belirlemekte yardımcı olacak daha ayrıntılı bir tedavi algoritması ise Şekil 8'de sunulmuştur.

1. Başparmağın metatarsın eksenine getirilmesi. Birinci basamağında yüksek HVA düzeltilir, parmak metatarsın eksenine getirilir. Bu amaçla kullanılacak cerrahi yöntem MTF eklemin uyumlu veya uyumsuz olmasına göre belirlenir. 


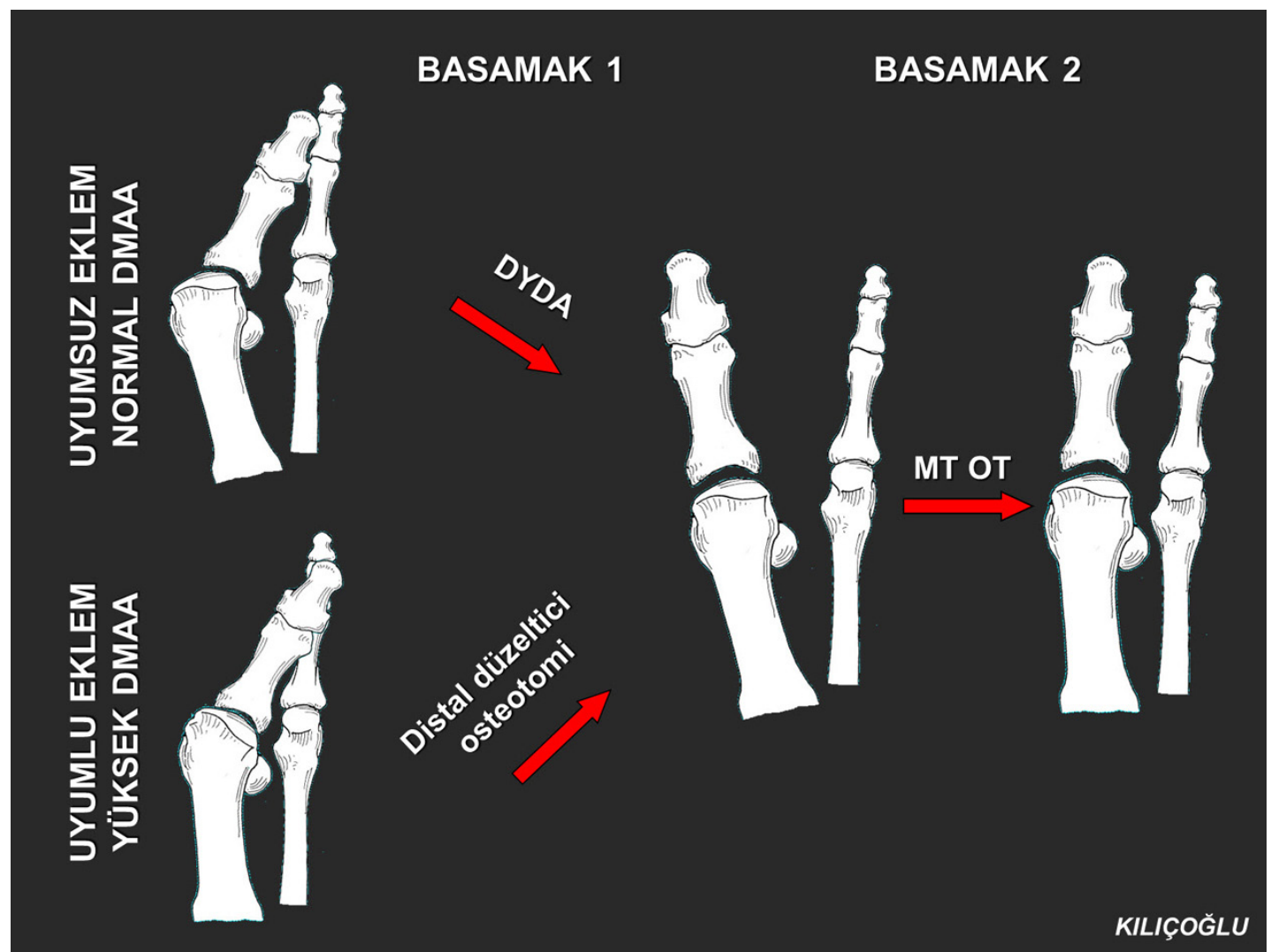

Şekil 7. İki basamaklı basit bir algoritma. Birinci basamakta parmak metatarsın eksenine getirilir. İkinci basamakta birinci metatars ikinciye yaklaştırılır.

a. Uyumsuz, yani laterale sublukse olmuş bir MTF eklemde "distal yumuşak doku ameliyatı" kullanılır. Silver ${ }^{[20]}$ tarafından yaygınlaştırılan yumuşak doku girişimi için daha sonraları birçok alternatif önerilmiştir. MTF eklemin lateralindeki kontrakte dokuların (lateral kapsül ve adduktor hallusis tendonu ve transvers metatarsal bağ) gevşetilmesi ve mediyaldeki dokuların büzüştürülmesi tümünün ortak özelliğidir. Büyük bir mediyal çıkıntısı olan olgularda başın mediyalinin traşlanması da yumuşak doku girişiminin parçası olarak kabul edilir. McBride ${ }^{[21]}$ bu girişim sırasında lateral sesamoidin alınmasını önermiş, ilerleyen yıllarda bunun HV'ye yol açtığı gözlenerek vazgeçilmiştir. ${ }^{[22]}$

b. Uyumlu, yani yüksek DMAA'lı hastalarda yumuşak doku girişimi ile parmağı metatarsın ekseni üzerine getirmek eklemin varus yönünde sublukse edilmesine neden olur. Bu olgularda yumuşak doku girişimi yerine "distal döndürücü metatarsal osteotomi” ile başın varusa döndürülmesi gerekir. 1881 yılında Reverdin'in tanımladığı mediyal kapayıcı kama osteotomisi yalnızca DMAA'yı düzelten bir osteotomidir. ${ }^{[23]}$ IMA 1-2'yi daraltması mümkün olmadığı gibi stabil bir osteosentez sağlamak da güçtür. Bu nedenle günümüzde hem DMAA düzelten hem de IMA 1-2'yi daraltabilecek çok planlı osteotomiler tercih edilmektedir. Bunlar arasında en çok bilinen "biplanar Chevron osteotomisi"dir.

2. Metatars başlarının birbirine yaklaştırılması: Girişimin birinci basamağında, parmak birinci metatarsın eksenine getirildiğinde birinci ve ikinci parmakların arasının çok açıldığı görülür (Şekil 7). Ayak bu şekilde bırakılırsa, ayakkabı giyimine başlar başlamaz birinci parmak ikinciye doğru yaklaşacak, bunion tekrar ortaya çıkacaktır. Nüksü önlemek için metatars başlarının birbirine yaklaştırılması, ayağın daraltılması gerekir. Bu amaçla geliştirilmiş çok sayıda şeklen farklı, ancak özünde birkaç grupta sınıflanabilecek osteotomi bulunmaktadır. Cerrahın görevi her hasta için uygun olan tekniği belirlemektir. Aşağıda metatarsal osteotomilerin özellikleri 


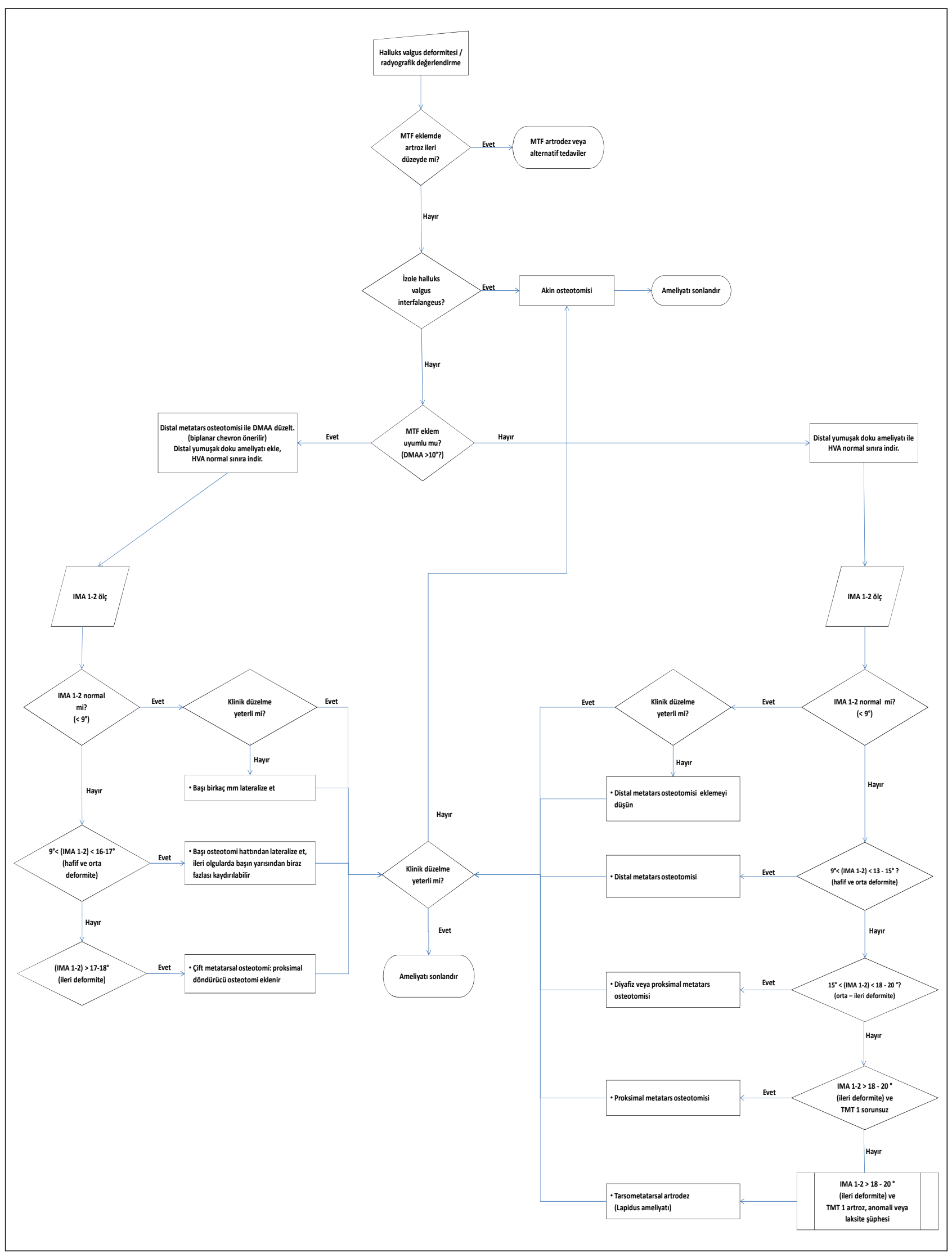

Şekil 8. HV tedavisinin özetlendiği kapsamlı algoritma. 


\section{Döndürücü tip}

\section{Kaydırıcı tip}
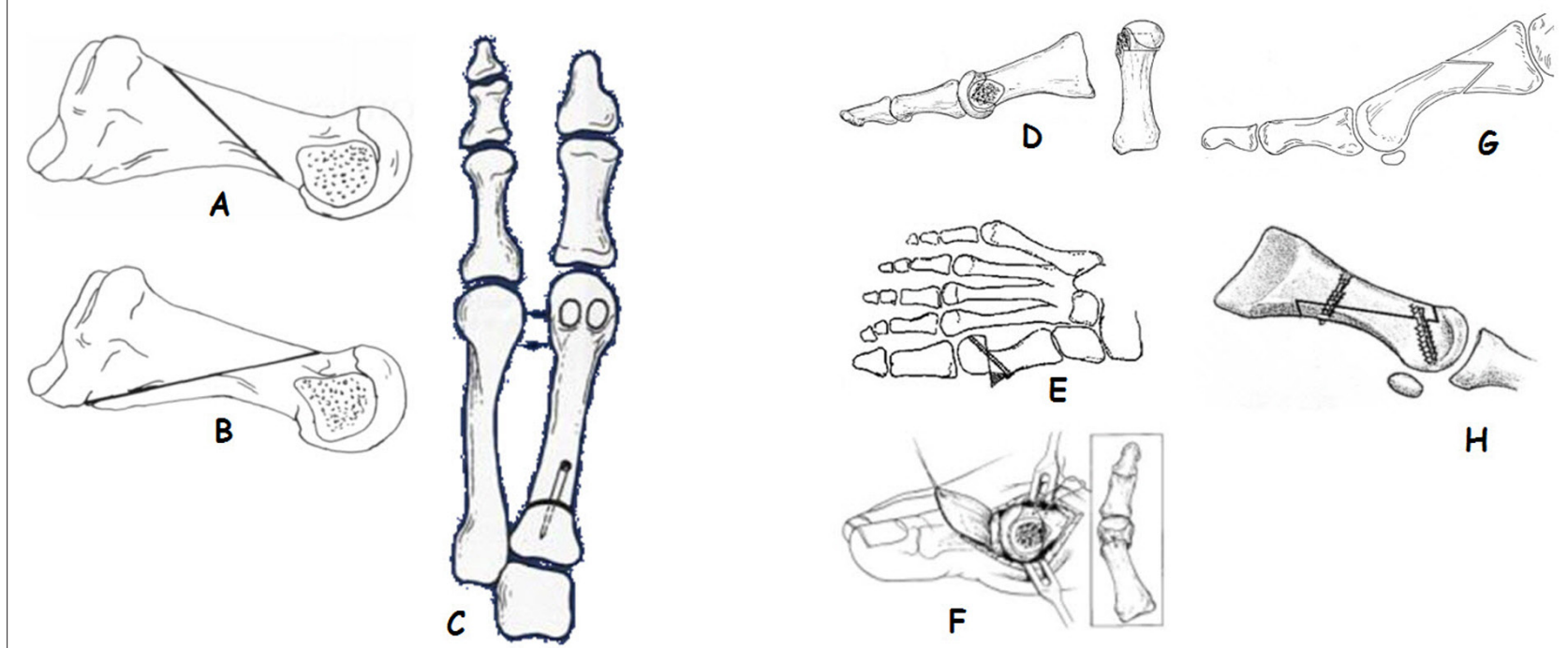

H

Şekil 9. Metatars osteotomileri etki mekanizmalarına göre iki ana gruba ayrılabilir: Ludloff (A), Mau (B) ve proksimal hilal (kubbe) (C) osteotomileri gibi döndürücü osteotomiler ve Chevron (D), Wilson veya Lindgren-Turan (E), Mitchell (F), proksimal Chevron $(\mathrm{G})$ ve $\operatorname{scarf}(\mathrm{H})$ gibi kaydırıcı osteotomiler.

ve seçim kriterleri ayrıntılı olarak incelenmiştir. Çok az sayıda olguda MTK eklemden kaynaklanan bir deformiteye rastlanır. Sıklıkla pes planovalgus'un da eşlik ettiği bu hastalarda düzeltme yanında stabilite de sağlamak amacı ile MTK ekleme artrodez uygulanabilir (Lapidus ameliyatı). ${ }^{[24]}$

\section{Metatarsal osteotomiler}

Metatars başlarını birbirine yaklaştırarak ayağı daraltmayı sağlayan çok sayıda metatarsal osteotomi çeşidi tanımlanmıştır. Bu osteotomiler yerleşimlerine, etki mekanizmalarına, stabilitelerine ve kemiğin boyu üzerindeki etkilerine göre incelenebilir.

Osteotomi sonrasında metatars distali laterale doğru itiliyorsa "kaydırıcı", osteotomi hattından itibaren dışa doğru döndürülüyorsa "döndürücü" bir osteotomiden bahsederiz (Şekil 9). Klasik bir bilgi olarak, osteotomi proksimale yaklaştıkça daha düşük döndürme açıları ile çok daha fazla daralma sağlamaktadır. Distal osteotomiler yalnızca laterale kaydırıcı, proksimal osteotomiler ise yalnızca dışa döndürücüdür. Diyafız osteotomileri ise genellikle her ikisini de içerir.

Osteotomiler yerleşimlerine göre distal, diyafizer ve proksimal olarak sınıflanabilir:

1. Distal osteotomiler: Metatars başı içinden başlayarak metafiz-diyafiz bileşkesine kadar olan bölgede yer alırlar. Tipik örnekleri Chevron ${ }^{[25]}$ ostetomisi,
Mitchel/[26] osteotomisi ve Wilson ${ }^{[27]}$ osteotomisidir. Wilson osteotomisinde kesi hattı diyafizin ekseni ile 45 derece açı yapar ve lateral kaydırma kadar kısalmaya da neden olur. Bu nedenle teknik Lindgren ve Turan tarafından modifiye edilmiş, osteotomi hattı 30 dereceye kadar yataylaştırılarak kısalma oranı azaltılmıştır. ${ }^{[28]}$ Yine de ikinci metatarsı uzun hastalarda bu osteotominin tercih edilmemesi gereklidir. Mitchell osteotomisi invaziv bir teknik olması, uygulama zorluğu ve metatarsı kısaltması nedeni ile tercih edilmez. Chevron osteotomisi ise Wilson osteotomisine göre biraz daha zor olmakla birlikte metatarsa çok daha az hasar veren bir osteotomi şeklidir. Üçgen osteotominin tepesi başın içindedir ve metatars başının yarısına kadar laterale kaydırma şansı tanır. Baş metatarsın en geniş yeri olduğu için IMA 1-2'de belirgin bir azalma sağlanır. Metafizer bölgede olduğu için kaynama sorunu olmaz, osteotominin şekli nedeniyle tek bir tel veya vida ile stabil tespit sağlanabilir. Eğer osteotomi hattı doğru planlanırsa en fazla testere kalınlığı kadar kısalmaya neden olur. Sayılan bu nedenlerle Chevron osteotomisi distal osteotomiler arasında en çok tercih edilen yöntem olmuştur. DMAA yüksek olan hastalarda ise Chevron osteotomisi neredeyse tek seçenek olarak karşımıza çıkar. Chevron kesisi çift planda yapılarak hem DMAA düzeltilir, hem de baş laterale kaydırılabilir (Şekil 10). 

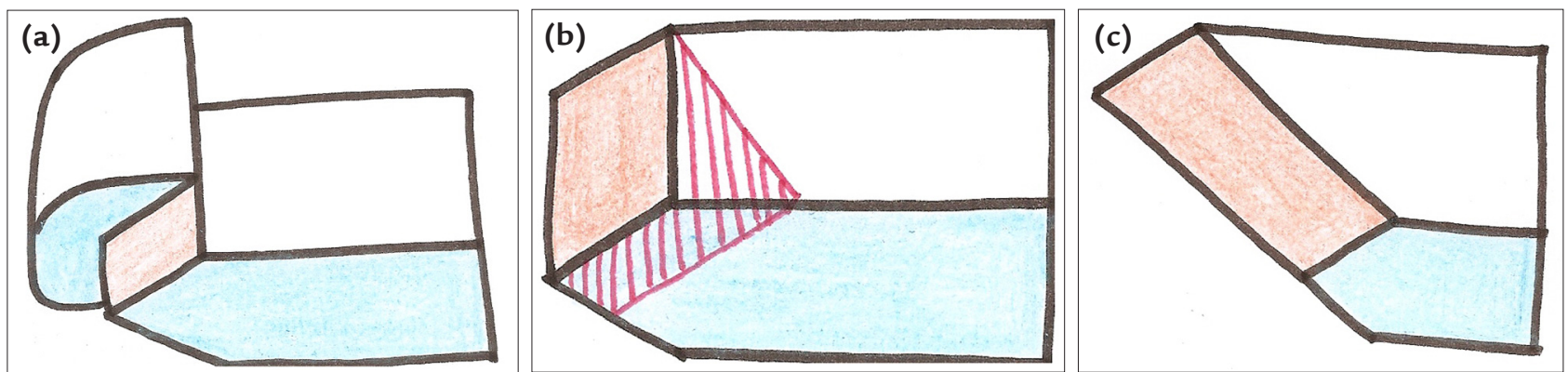

Şekil 10. a-c. Chevron osteotomisi. a) Klasik Chevron ile dış yana kaydırma. b) Biplanar Chevron'da proksimal fragmanın dorsalinden kama çıkarılır. c) Osteotomi sonrası proksimal fragmanın aldığı şekil.

Metatars başı ne kadar geniş ise distal osteotomilerin düzeltme kapasitesi o kadar yüksektir. Başın laterale sorunsuz olarak itilebileceği mesafe baş genişliğinin yaklaşık yarısı kadardır. Distal bir osteotomi ile IMA 1-2'de 5-7 derece kadar düzelme sağlamak mümkün olmaktadır.

2. Diyafiz osteotomileri: Ludloff ${ }^{29]}$ ve Mau osteotomileri tipik oblik diyafiz osteotomileridir. Her ikisi de döndürerek düzeltme sağlar. Ludloff osteotomisi daha yaygın kullanılır. Osteotominin düz yüzeyleri stabil bir yüzey sağlamaz, ancak iki vida ile osteosentez yapıldığında yeterli tespit sağlandığı kabul edilir. Metatarsın "Z" şeklinde kesildiği scarf osteotomisi de diyafiz osteotomilerinden birisidir. ${ }^{[30]}$ Distal ve proksimalde yaratılan kamalar nedeni ile iç stabilitesi yüksektir. Özgün scarf tekniğinde yalnızca laterale kaydırma kullanılır. Bu teknik zamanla birçok şekilde modifiye edilmiş, DMAA'sı yüksek hastalarda da kullanılmak üzere mediyal rotasyon dahi eklenmiş̧tir. ${ }^{[31]}$ Geniş bir açılım gerektirmesi, teknik zorluğu nedeni ile yaygın kullanım alanı bulamamıştır. Diyafiz osteotomilerinde özellikle osteoporotik hastalarda osteosentez sorunlarıla sık karşılaşılır. İncelmiş korteksler kaydırma veya döndürme sonrasında içe içe geçerek düzeltmeye engel olabilirler.

3. Proksimal osteotomiler: Proksimal metafiz bölgesinden yapılan bir osteotomi ile diyafizin laterale döndürülmesi IMA 1-2'yi en etkili şekilde daraltan tekniktir. Hemen her zaman distal yumuşak doku girişimi ile birlikte uygulanır. Osteotomi lateral kapayıcı kama, mediyal açıı kama ve kubbe ostetotomisi $^{[5]}$ şeklinde olabilir. Kubbe osteotomisi ile düzeltmenin bir üst sınırının olmaması ve kısalık veya uzunluğa yol açmaması nedeniyle en sık tercih edilen yöntem olmuştur. Basis parçasının küçük olması nedeniyle özellikle osteoporotik hastalarda tespit sıkıntısı yaşanabilir. Ayrıca, sagittal planda hatalı kaynama ile sık karşılaşılması gibi nedenlerle cerrahlar bu bölgede osteotomi yapmaktan uzun yıllar kaçınmıştır. Son yıllarda yaygınlaşan kilitli anatomik plaklar sayesinde stabil bir osteosentez sağlamak kolaylaşmış, kubbe osteotomisi yanında açıcı kama tekniği de günlük pratikte daha sık uygulanmaya başlanmıştır. MTK artrodezde proksimal osteotomilerin lateral kapayıcı kama şeklinde olanları ile benzer özelliklere sahiptir. Stabil bir osteosentez sağlanabilmesi, IMA 1-2'de çok yüksek düzeltme kapasitesine (10-15 derece) sahip olması önemli üstünlükleridir.

\section{Falanks osteotomisi}

Deformitenin proksimal falanksta olduğu nadir durumlarda (HVI) düzeltmenin de falankstan yapılması gereklidir. Akin osteotomisi çok uzun süreden beri klinik kullanımda olan, basit, ancak etkili bir mediyal kapayıcı kama osteotomisidir. ${ }^{[32]}$ Tek başına kullanılabileceği gibi, deformitenin klinik olarak yeterince düzeltilemediğine inanılan olgularda yardımcı yöntem olarak da uygulanabilir.

\section{Sonuçlar}

HV cerrahisi genel olarak başarılı bir tedavi yöntemidir. Yayımlanan serilerin büyük kısmında $\% 90$ oranında yeterli radyografik düzelme ve ağrıda azalma bildirilmektedir. Hastaların yaşam kalitesinde de önemli bir artış olduğu, hatta genel değerlendirme skorlarının yaşıtlarının ortalamalarının üzerine çıktığı görülmektedir. ${ }^{[33]}$ Karşılaştırmalı çalışmalarda farklı osteotomi tipleri ile elde edilen sonuçlar arasında önemli bir farklılık saptanmamıştır. ${ }^{[17]}$ Klinik başarı radyografik düzelme ile paralel değildir, açılardaki düzelmenin yetersizliğine rağmen klinik düzelme yeterli seviyede olabilmektedir. ${ }^{[17,34]}$ Öte yandan, hastalara sorulduğunda \%25-33'ünün beklentilerinin aslında tam olarak karşılanmadığını da görmekteyiz. ${ }^{[17,35]}$ Amerika Birleşik Devletleri'nde dava konusu olan 325 ortopedik 
sorunun \%24'ünün ayak ameliyatı, bunun da \%60'ının metatars osteotomisi ile ilişkili olduğu dikkate alırsak bu tatminsizliğin yol açabileceği sorunları daha kolay anlayabiliriz. ${ }^{[36]}$

Sonuç olarak, Rowley'in bir editörden yazısında vurguladığı gibi, biz hangi yeni osteotomi tekniğini geliştirirsek geliştirelim, hastaların en fazla \%90'ını memnun etmeyi başarabileceğiz. ${ }^{[37]}$

\section{HALLUKS RIGIDUS (HR)}

HR birinci MTF eklemin artrozuna bağlı, hareket kısıtlılı̆ı ve ağrı ile seyreden bir klinik tablodur. Hareket kısıtlılığı eklem dışı nedenlerden kaynaklandığında halluks limitus, fleksus veya ekstensus gibi farklı isimlendirmelerin kullanılması doğru olur. HV'ye göre çok daha kısıtlayıcı bir sorun olan bu tablo, 50 yaş üzerindeki 40 kişiden birinde görülür. ${ }^{[38]}$ Farklı evrede olsalar da olguların \%80'inde iki taraflı tutulum vardır. Yine \%80'inin ailesinde aynı hastalık tespit edilmektedir.

\section{Etiyoloji}

Çok sayıda nedenden bahsedilmekle birlikte, sebepsonuç ilişkisi kesin kurulabilen tek neden travmadır. Tek taraflı olgularda genellikle eklem içi kırıklar gibi büyük bir travma öyküsü vardır. Farkına varılmamış, unutulmuş kondral veya osteokondral yaralanmalar da uzun dönemde artroza neden olabilir. Travma dışında sistemik romatizmal hastalıklar da MTF eklem artrozuna yol açar. Bunların dışında bazı anatomik farklııkların HR'ye sıklıkla eşlik ettiği bilinmektedir: Belirgin şekilde kısa birinci metatars (Morton ayağı), koni şekilli veya düz metatars başı ve HVI.

\section{Klinik tablo ve muayene}

HR, HV'a göre çok daha kısıtlayıcı bir hastalıktır. Tipik bir HR hastası yürürken MTF eklemde ortaya çıkan ağrı yakınması ile başvurur. Hareket kısıtlılığı yakınması çok daha geri plandadır. ileri evredeki bazı hastalar hareket azaldıkça ağrısının azaldığını ifade edebilir. HR hastasının karakteristik bir özelliği HV hastasının aksine, ayakkabı giyince rahat etmesidir. Bu hastalar evde dahi ayakkabı ile yürümek zorunda olduklarını söylerler. Hastaların bir kısmı eklem çevresindeki şişliklerin ayakkabıyla teması nedeniyle ortaya çıkan bursit ve ağrıdan yakınır. Osteofitler ile ayakkabı arasında sıkışan kutanöz sinirlerin yanma şeklinde ağrı yapması ve baş parmağın dorsalinde hipoestezi oluşması daha az görülen bulgulardır.

Klinik değerlendirmede MTF eklemin hareket açıklığı kontrol edilir. Sıklıkla dorsifleksiyon kısıtlıdır, nadiren parmak nötrale dahi gelemez ve sürekli olarak dorsale itilen birinci metatars topuk varusuna neden olabilir. Hareket kısıtlılı̆ına yol açabilen diğer bir patoloji de fleksor hallusis longus (FHL) tendonunun kısalığıdır. Ayak bileği plantar fleksiyona getirildiğinde MTF eklem dorsifleksiyonunda artış olması FHL kısalığının bulgusudur. Hareket muayenesi sırasında ağrının beklenenden daha şiddetli olabileceği unutulmamalı, yumuşak hareketler ile başlanmalıdır. Hastanın esas yakınmasının nereden kaynaklandığı özellikle sorgulanmalıdır. Hareket kısıtlılığının şiddetinin ağrı ile paralel seyretmeyebileceği unutulmamalı, bursitler, nöromalar gibi olası diğer nedenler sorgulanmalıdır. HR hastalarında ayak genellikle genişlememiştir, diğer parmaklarda ileri deformiteler bulunmaz. Ek sorunların varlığı sistemik hastalıkları akla getirmelidir.

\section{Radyolojik değerlendirme}

HR'nin tanısı ve takibi için ayakta basarak çekilen $A P$ ve lateral standart radyografiler yeterlidir. Işın ayak sırtına dik gelecek şekilde, yaklaşık 15 derece yatırılarak yapılan AP çekimlerde eklem aralığının daha doğru değerlendirilmesi mümkün olur (Şekil 11). Manyetik rezonans görüntüleme gibi ek yöntemler tanı koymak için değil, cerrahi tedavi kararı verilen hastada cerrahi teknik seçimi için yardımcı olabilir.

\section{Evrelendirme}

Couglin tarafindan önerilen hem radyografik hem de klinik parametreleri dikkate alan evrelendirme cerrahi tedavi seçiminde de yardımcı olduğu için en fazla kabul gören sınıflandırma olmuştur (Tablo 2). ${ }^{[39]}$ Eklem yüzeyinin dorsal \%50'sinden fazlasının aşınmış olması, hareket açıklığının orta bölümlerinde dahi ağrı olması önemli olumsuz prognostik faktörlerdir. ${ }^{[39]}$

\section{Tedavi}

Her artroz hastasında olduğu gibi HR'de de yakınma düzeyi en başta olmak üzere, klinik ve radyografik bulgulara göre bir tedavi planlaması yapılır. Couglin'in evrelendirmesi tedavi planlaması için önemli bir yardımcıdır. Konservatif tedavi HV'nin tersine, HR'de önemli yeri olan bir seçenektir. Cerrahi tedavi teknikleri ise daha az sayıda olmakla birlikte daha çeşitlidir.

\section{Konservatif tedavi}

HR'nin konservatif tedavisinin temeli MTF eklemin hareketini kısıtlamaya dayanır. Ayağın ön kısmında sorunu olan hastaların genellikle tercih ettikleri yumuşak tabanlı, esnek ayakkabılar HR hastaları için en uygunsuz tercihtir. Bu hastaların sert tabanlı, mümkünse yürüyüşs sırasında ayak ön kısmının dorsifleksiyonuna hiç 

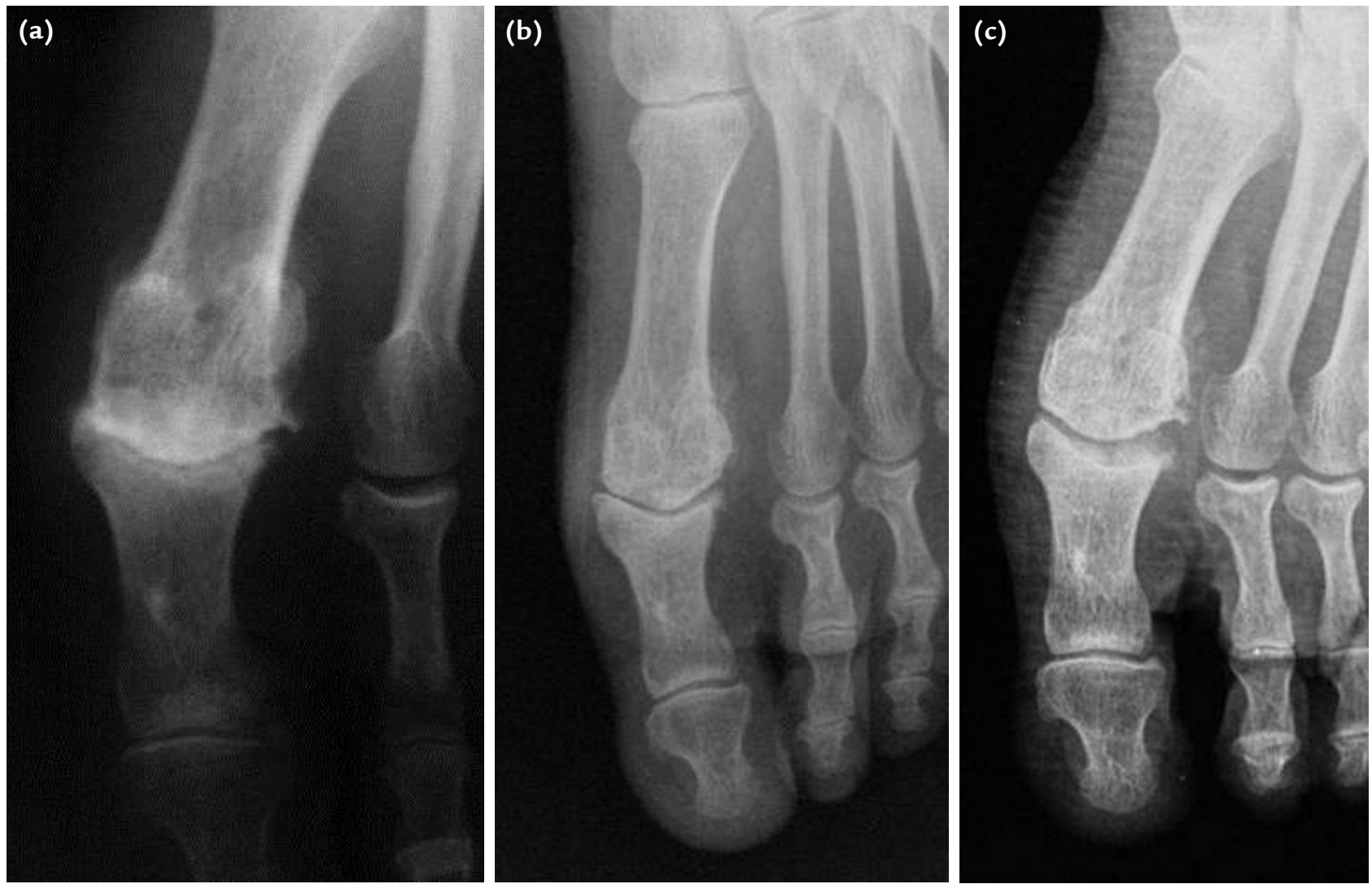

Şekil 11. a-c. a) HR hastasında standart pozisyonda çekilen basarak AP grafide eklem aralığı kapalı görülüyor. b) Röntgen tüpü distale doğru 15 derece yatırılarak çekilen AP grafide eklem aralığının henüz korunduğu görülmekte. c) Çeilektomi girişimi sonrası eklem aralığındaki açılma görülmekte.

Tablo 2. HR için klinik ve radyolojik evrelendirme (Coughlin). ${ }^{[39]}$

\begin{tabular}{|c|c|c|c|}
\hline Evre & Dorsifleksiyon & Radyografik bulgular & Klinik bulgular \\
\hline 0 & $40^{\circ}$ ile $60^{\circ}$ arasında veya normal tarafin $\% 10-20$ altında & Normal & Ağrı yok, yalnızca hareket kısıtlılığı \\
\hline 1 & $30^{\circ}$ ile $40^{\circ}$ arasında veya normal tarafin $\% 20-50$ altında & $\begin{array}{l}\text { Esas bulgu dorsalosteofit, } \\
\text { eklem aralığında hafif daralma, } \\
\text { hafif eklem çevresi skleroz, } \\
\text { metatars başında hafif düzelme }\end{array}$ & $\begin{array}{l}\text { Hafif ve nadiren ağrılı, } \\
\text { dorsifleksiyonun veya plantar } \\
\text { fleksiyonun uç noktalarında ağrılı }\end{array}$ \\
\hline 2 & $10^{\circ}$ ile $30^{\circ}$ arasında veya normal tarafin $\% 50-75$ altında & $\begin{array}{l}\text { Dorsal, lateral ve bazen } \\
\text { mediyalosteofitler metatars } \\
\text { başının düzeldiği izlenimi verir, } \\
\text { lateral grafide dorsal eklem } \\
\text { aralığının 31/1'׳ü korunmuştur, } \\
\text { eklem aralığındaki daralma } \\
\text { hafif ve orta düzeyde, } \\
\text { sesamoidler sıklıkla tutulmuş }\end{array}$ & $\begin{array}{l}\text { Sürekli olabilen orta veya şiddetli } \\
\text { düzeyde ağrı; ağrı dorsifleksiyon ve } \\
\text { plantar fleksiyonun üst sınırlarında } \\
\text { oluşur }\end{array}$ \\
\hline 3 & $\begin{array}{l}\leq 10^{\circ} \text { veya normal tarafın } \% 75-100 \text { altında. } \\
\text { Genellikle MTF plantarfleksiyonda da belirgin kısıtlılık } \\
\text { görülür (sıklıkla } \leq 10^{\circ} \text { ) }\end{array}$ & $\begin{array}{l}\text { Evre } 2 \text { gibi ancak belirgin } \\
\text { daralma, eklem çevresi kist } \\
\text { oluşumu, lateral grafide } \\
\text { dorsalde eklem genişliğinin } \\
\text { 1/4'ünden fazla daralma, } \\
\text { sesamoidler genişlemiş, } \\
\text { düzensiz veya kistik yapılar var }\end{array}$ & $\begin{array}{l}\text { Sürekli sayılabilecek ağıı ve belirgin } \\
\text { hareket kısıtlılığı; ağrı hareket } \\
\text { açıklığının üst sınırlarında belirgin, } \\
\text { ortada yok }\end{array}$ \\
\hline 4 & Evre 3 gibi & Evre 3 gibi & $\begin{array}{l}\text { Evre } 3 \text { gibi, ANCAK hareket } \\
\text { açıklığının orta kısmında dahi ağıı } \\
\text { var }\end{array}$ \\
\hline
\end{tabular}




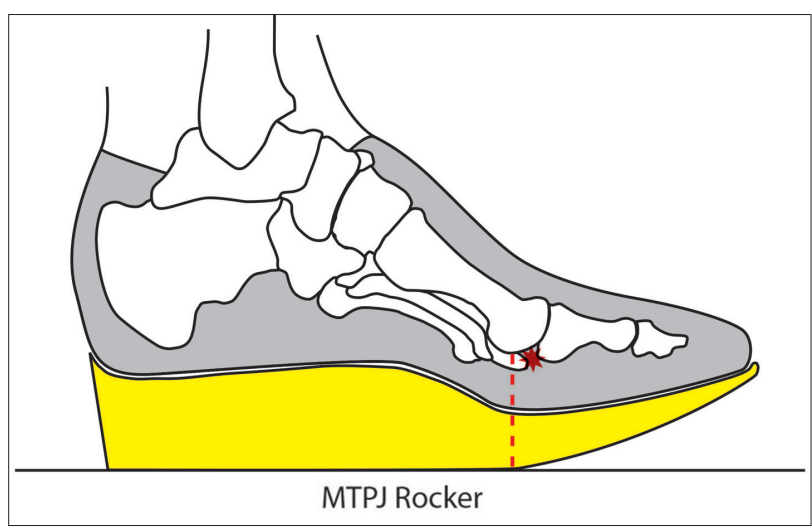

Şekil 12. MTF eklem yük gelmesini önleyen ön ayak beşik tabanlı ayakkabı

(http://www.eneslowshoes.com/media/images/2012/10/MTPJ-Rocker2.jpg).

izin vermeyen ayakkabılar giymesi gerekir. Sert tabanlı bir ayakkabı ile rahat yürüyebilmesi için de tabanın en azından ön kısmında beşik taban şekli verilmiş olmalıdır (Şekil 12). Hastaların önemli bir kısmının zaman içinde bu tanıma uyan ayakkabıları tercih etmiş olduğunu görmekteyiz. Ayakkabı modifikasyonu ile günlük yaşamda belirgin bir rahatlama ve cerrahi girişimde uzun süreli bir erteleme sağlanmaktadır. MTF eklem hareketini kısıtlamak amacıyla ayakkabı içine yerleştirilen özel, sert tabanlıklar da hazırlanabilir. Ancak hastalar bu tabanlıkların kullanımının rahat olmadığını ifade etmektedir.

Illeri derecede inflamasyonu olan, erken evredeki hastalarda eklem içi steroid yapılarak akut atağın kısa sürede rahatlamasını sağlamak elimizdeki önemli silahlardan birisidir. İki-üç haftalık bir rahatlama sağlayan steroid enjeksiyonundan sonra sert tabanlı ayakkabı ile takip ederek ağrılı atakların arasının açılması mümkün olur. Dorsal osteofitlerin ayakkabı ile temasından kaynaklanan sorunlar yüksek burunlu ayakkabılar ve silikon destekler ile kolayca çözülebilir.

\section{Cerrahi tedavi}

HR'nin tedavisi için önerilen cerrahi yaklaşımlar arasında eklemi koruyan eklem debridmanı, osteofit eksizyonu, çeilektomi, distal metatars osteotomileri, falanks osteotomisi gibi teknikler ve eklemi feda eden rezeksiyon artroplastisi, sınırlı eksizyon artroplastileri, interpozisyon artroplastileri, implant artroplastileri ve artrodez yer alır.

Eklem debridmanı; sinovitin ön planda olduğu tablolarda eklem yıkımını yavaşlatmak ve kısmi bir rahatlama sağlamak amacıyla, nadiren tercih edilen bir yaklaşımdır. Osteofit eksizyonu; hareket açıklığını azaltan veya ayakkabı ile temas ederek hastaya sıkıntı yaratan
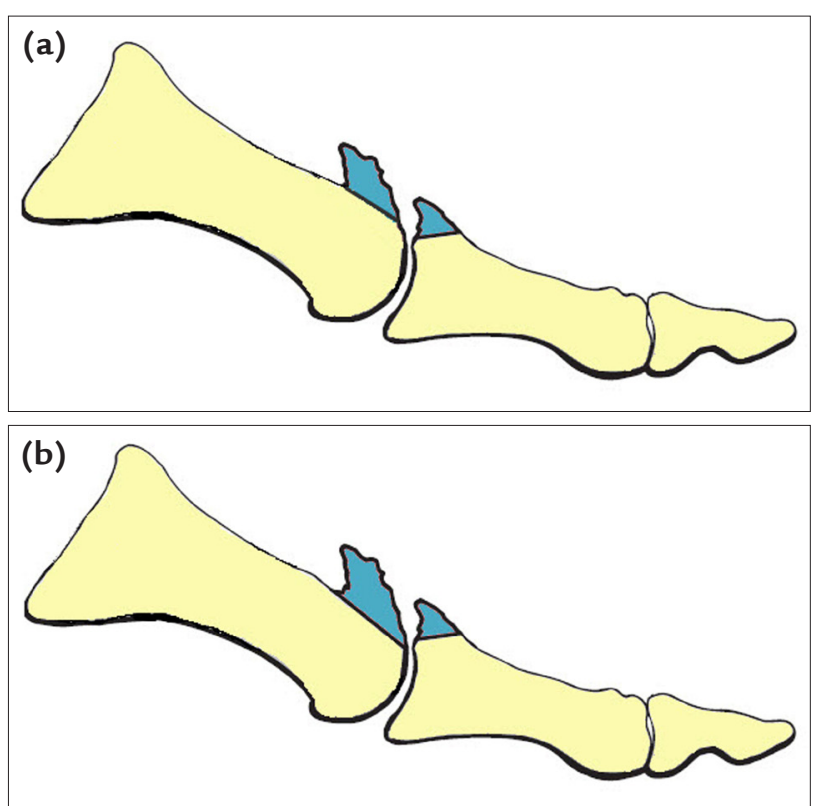

Şekil 13. a, b. Osteofit eksizyonu ve çeilektomi. a) Osteofit eksizyonunda dorsal kenarın hizasının plantarına geçilmez. b) Çeilektomide metatars başında eklem yüzünün dorsal \%20-30 kısmı alınır.

eklem çevresi osteofitlerin çıkarılmasıdır (Şekil 13a). Eklem yüzeyi korunmuş, osteofitlere bağlı yakınmaların baskın olduğu hastalarda tercih edilir. Çeilektomide ise metatars başının dorsal \%20-30'u da osteofit ile birlikte eksize edilir (Şekil 11c ve 13b). Hareketi kısıtlanmış, ancak artrozu eklemin dorsal \%50'ini aşmamış olgularda kullanılır. Aynı anda sinovektomi yapılır, kapsüldeki, sesamoidlerdeki yapışıklıklar da serbest bırakılır. Tüm bu girişimlerde ameliyat sırasında ölçülen hareket açıklığının 70 dereceye kadar ulaşması amaçlanır. Ameliyat sırasında elde edilen açıklık ameliyat sonrasında en az 20 derece kadar azalacaktır.

Ameliyat sırasında arzu edilen hareket açıklığına ulaşılamadığı takdirde daha radikal rezeksiyon da yapılabilir. Valenti ameliyatı; metatars başının dorsal üçte birinin ve proksimal falanksın basisinde plantar tarafi koruyarak dorsal bir kamanın çıkarıldığı radikal bir çeilektomidir (Şekil 14). Plantar aponevroz korunduğu için stabilite sorunu görülmez. Parmak dorsifleksiyonunu arttırmak için kullanılabilecek diğer bir seçenek de proksimal falanks basisinden yapılacak bir dorsal kapayıcı kama osteotomisi ile (Moberg osteotomisi) parmak dorsifleksiyonunu kalıcı olarak arttırmaktır (Şekil 15). Basit ve etkili bir girişimdir.

Artrozun ilerlemiş olduğu düşünülüyorsa ağrının geçirilebilmesi için eklemin gözden çıkarılması gerekecektir. Bunun en kısa yolu Keller ameliyatı olarak da 


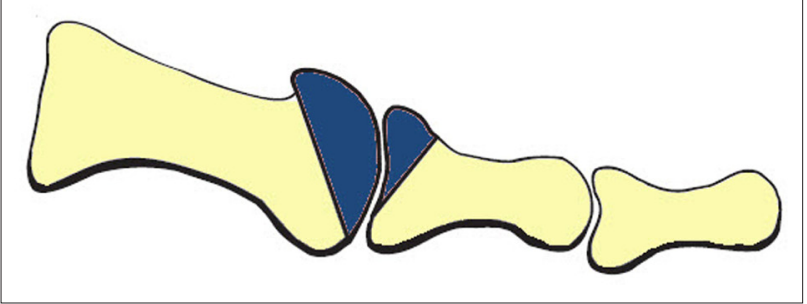

Şekil 14. Valenti ameliyatı plantar aponevrozun falanksa yapışma bölgesini korur.

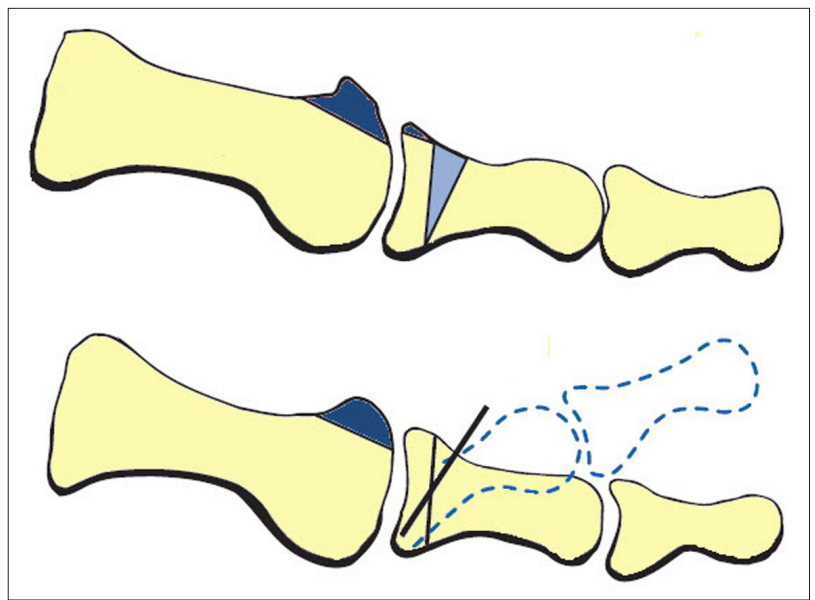

Şekil 15. Moberg falanks osteotomisi.

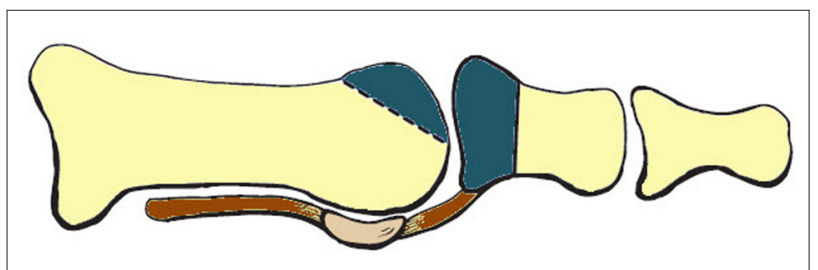

Şekil 16. Keller ameliyatı.

bilinen eksizyon artroplastisidir (Şekil 16). Bu girişimde proksimal falanksın proksimal eklem yüzünü içeren $1 \mathrm{~cm}$ 'lik kısmı transvers olarak eksize edilir. Metatars başının dorsalinde ise çeilektomi uygulanır. Plantarda ayrılmış olan aponevroz ve kapsül falanks basisine açılan dikişlerle tespit edilerek plantar fleksiyon gücü korunmaya çalışıı. Parmağın itme gücünü ve hatta stabilitesini kaybetmesi, parmağın ekstansiyonda kilitli kalabilmesi gibi nedenlerle günümüzde gençlerde hiçbir zaman önerilmemektedir. Rezeksiyon sonrasında kemik yüzeylerin temasını engellemek için çevre yumuşak dokuların eklem boşluğuna doldurulması da önerilmiştir (interpozisyon artroplastisi). Dorsal eklem kapsülünün ekstansör hallusis brevis tendonu ile birlikte plantar aponevroza dikilmesi en sık tercih edilen yöntemdir (Şekil 17).

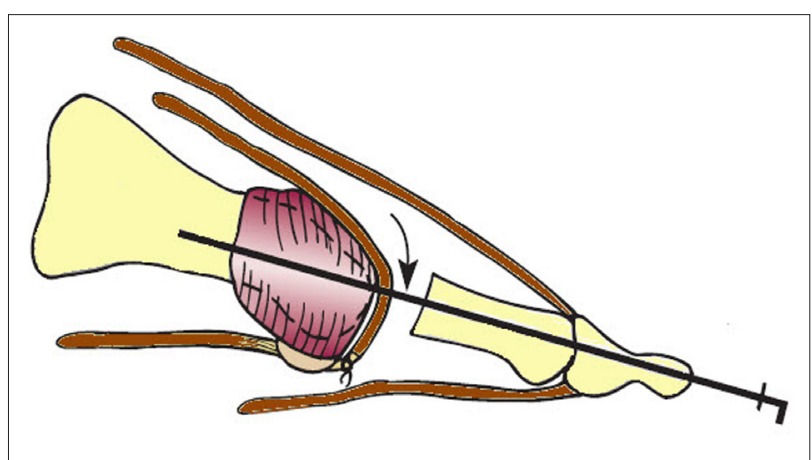

Şekil 17. İnterpozisyon artroplastisinde dorsal kapsül ve ekstansor hallusis brevis tendonu eklem aralığını kapatmak için kullanılır.

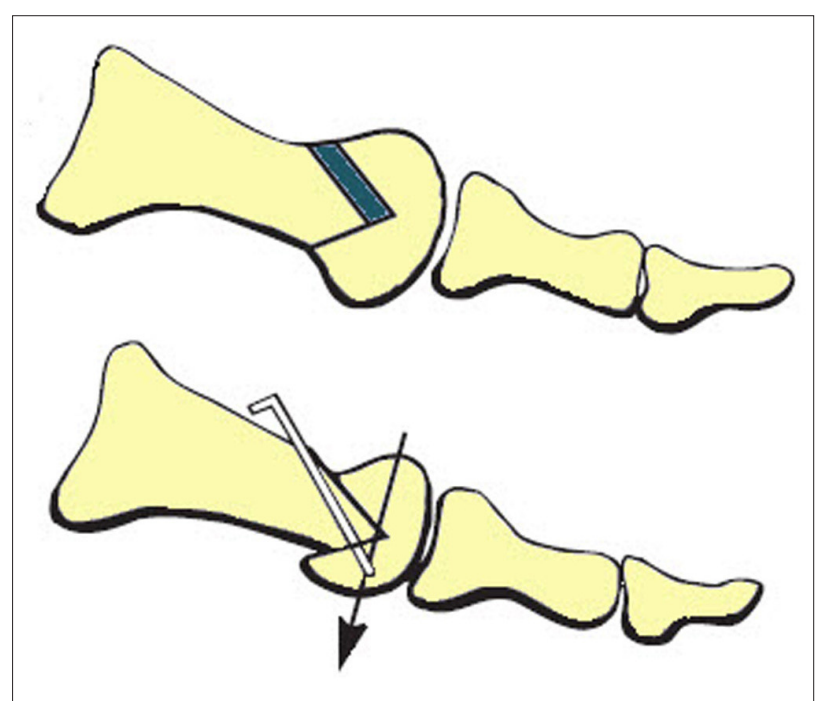

Şekil 18. Green-Waterman osteotomisi metatars başının plantara kaydırılmasını sağlayan bir tür biplanar Chevron osteotomisidir.

HR etiyolojisinde metatarsın ekstansiyonunun yer aldığı hipotezine dayanılarak önerilen bir cerrahi tedavi grubu da metatarsı fleksiyona getiren osteotomilerdir. Metatars basisinde plantar yüzden yapılan kapayıcı kama osteotomisi veya plantara kaydırılan modifiye Chevron osteotomileri (Green-Waterman osteotomisi) en bilinen örnekleridir (Şekil 18). MTF eklemin hareketi cerrahi olarak arttırıldığında metatarstaki ekstansiyonun kendiliğinden düzeldiği gözlendiğinden bu osteotomiler ortopedik cerrahlar arasında yaygın kullanım alanı bulmamıştır. ${ }^{[39]}$ Metatars başında, plantarda kalan kıkırdak kısmından faydalanmak üzere geliştirilen diğer bir seçenek ise başın içinden yapılan kapayıcı kama osteotomisidir (Waterman osteotomisi) (Şekil 19). Bu osteotomi de kullanılmamaktadır.

Günümüzde ileri evredeki bir HR'de en sık tercih edilen iki yöntem MTF eklem artrodezi ve implant 


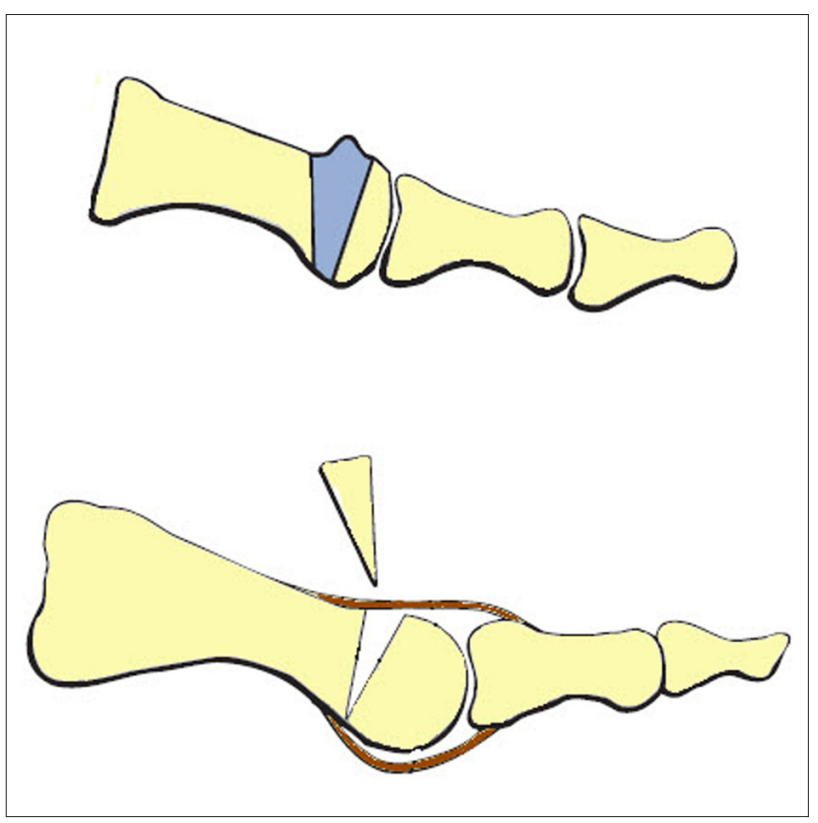

Şekil 19. Distal dorsal kapayıcı kama osteotomisi olan Waterman osteotomisi plantarda kalan sağlam kıkırdağı falanks hizasına yükseltmeyi amaçlar.

artroplastisidir. Artrodez uzun süreli takipleri bilinen, başarılı, güvenilir bir yöntem olmasına karşılık hareketi ortadan kaldırdığı için hastalar tarafından tercih edilmemektedir. MTF eklem artroplastisinin ilk yıllarında özellikle silikon implantlar ile elde edilen kötü sonuçlar uzun yıllar cerrahların bu eklemin artroplastisine çekinerek yaklaşmasına yol açmıştır. ${ }^{[40,41]}$ Günümüzde yeni implant seçenekleri ile daha başarılı sonuçlara ulaşılsa da karşılaştırmalı çalışmalar artrodezin daha güvenilir sonuçları olduğuna işaret etmektedir. ${ }^{[42,43]}$

Primer olguda artrodez için yüzey hazırlığı başarı üzerinde etkili bir etmendir. Küresel oyucular ile yüzeylerin hazırlanması hem tam uyumlu temas yüzeyi sağlar, hem de parmağa arzu edilen açılanmanın verilmesini çok kolaylaştırır. Osteosentez için çapraz iki vidadan standart veya anatomik plaklara, özel kompresyon vidalarından Kirschner tellerine uzanan geniş bir yelpaze kullanılabilir. Yivli Kirschner telleri ile dahi \%90'ların üzerinde başarı bildirilmektedir. ${ }^{[44]}$ Yine de, iyileşme sürecinde hastanın ayakkabı giymesine engel olmayacak ve gereğinde uzun süre tespit sağlayabilecek bir implant tercih edilmelidir. Yeterli kemik stoğu bulunan, osteoporotik olmayan hastalarda çapraz iki vida, revizyon olgularında ve defektli hastalarda ise düşük profilli, kilitli anatomik plaklar günümüzde tercih edilecek seçenekler olarak görülmektedir. ${ }^{[44]}$

Total MTF eklem artroplastisi sonuçları birçok seride yüz güldürücü olmaktan uzaktır. ${ }^{[45]} \mathrm{Bu}$ nedenle hemiartroplasti önemli bir seçenek olarak karşımıza çıkmaktadır. Metatars başının veya falanks proksimalinin replasmanı şeklinde yapılabilen hemiartroplasti 1950’lerden beri bilinse de 1994 yılında tekrar güncel bir konu haline gelmiştir. ${ }^{[46]} 2000$ 'li yılların ortasında piyasaya çıkan yüzey değiştirme implantı ile de oldukça başarılı sonuçlar bildirilmektedir. ${ }^{[47,48]}$ Yine de artrodezin en tatmin edici sonuçları verdiği unutulmamalıdır.

\section{KAYNAKLAR}

1. Kelikian H. Hallux Valgus, Allied Deformities of the Forefoot and Metatarsalgia. Philadelphia \& London: W.B. Saunders Company; 1965.

2. Coughlin MJ, Saltzman CL, Nunley JA 2nd. Angular measurements in the evaluation of hallux valgus deformities: a report of the ad hoc committee of the American Orthopaedic Foot \& Ankle Society on angular measurements. Foot Ankle Int 2002;23(1):68-74.

3. Schneider W, Knahr K. Metatarsophalangeal and intermetatarsal angle: different values and interpretation of postoperative results dependent on the technique of measurement. Foot Ankle Int 1998;19(8):532-6.

4. Richardson EG, Graves SC, McClure JT, Boone RT. First metatarsal head-shaft angle: a method of determination. Foot Ankle 1993;14(4):181-5.

5. Mann RA, Rudicel S, Graves SC. Repair of hallux valgus with a distal soft-tissue procedure and proximal metatarsal osteotomy. A long-term follow-up. J Bone Joint Surg Am 1992;74(1):124-9.

6. Mann JA. Hallux valgus, hallux varus and sesamoid disorders. In: Foot \& Ankle, Thordarson DB, editor. Philadelphia: Lippincott Williams \& Wilkins; 2004. p.113-30.

7. Coughlin MJ, Mann RA, Saltzman CL. Hallux valgus. In: Foot and Ankle Surgery. Coughlin MJ, Mann RA, editors. Mosby Inc.; 2007. p.183-362.

8. Coughlin MJ, Mann RA. The pathophysiology of the juvenile bunion. Instr Course Lect 1987;36:123-36.

9. Groiso JA. Juvenile hallux valgus. A conservative approach to treatment. J Bone Joint Surg Am 1992;74(9):1367-74.

10. Hardy $\mathrm{RH}$, Clapham JC. Observations on hallux valgus; based on a controlled series. J Bone Joint Surg $\mathrm{Br}$ 1951;33-B(3):376-91.

11. Coughlin MJ. Hallux valgus in the athlete. J Sports Med Arthrosc Rev 1994;2:326-40.

12. Noguchi $M$, Ikoma $K$, Inoue A, Kusaka $Y$. Bilateral hallux valgus associated with os intermetatarseum: a case report. Foot Ankle Int 2005;26(10):886-9.

13. Hyer CF, Philbin TM, Berlet GC, Lee TH. The incidence of the intermetatarsal facet of the first metatarsal and its relationship to metatarsus primus varus: a cadaveric study. J Foot Ankle Surg 2005;44(3):200-2.

14. Thordarson DB, Ebramzadeh E, Rudicel SA, Baxter A. Age-adjusted baseline data for women with hallux valgus undergoing corrective surgery. J Bone Joint Surg Am 2005;87(1):66-75.

15. Morton DJ. Hypermobility of the first metatarsal bone: the interlinking factor between metatarsalgia and longitudinal arch strains. J Bone Joint Surg Am 1928;10(2):187-96.

16. Tai CC, Ridgeway S, Ramachandran M, Ng VA, Devic N, Singh D. Patient expectations for hallux valgus surgery. J Orthop Surg (Hong Kong) 2008;16(1):91-5. 
17. Ferrari J, Higgins JP, Prior TD. Interventions for treating hallux valgus (abductovalgus) and bunions. Cochrane Database Syst Rev 2004;(1):CD000964.

18. Kilmartin TE, Barrington RL, Wallace WA. A controlled prospective trial of a foot orthosis for juvenile hallux valgus. J Bone Joint Surg Br 1994;76(2):210-4.

19. Gallentine JW, DeOrio JK. Removal of the second toe for severe hammertoe deformity in elderly patients. Foot Ankle Int 2005;26(5):353-8.

20. Silver D. The operative treatment of hallux valgus. J Bone Joint Surg 1923;5(2):225-32.

21. McBride ED. A conservative operation for bunions. 1928. J Bone Joint Surg Am 2002;84-A(11):2101.

22. Mann RA, Pfeffinger L. Hallux valgus repair. DuVries modified McBride procedure. Clin Orthop Relat Res 1991;(272):213-8.

23. Reverdin J. De la deviation en dehors du gros orteil (hallux valgus, vulg. "oignon", "bunions", "Ballen") et de son traitement chirurgical. Trans Int Med Congr 1881;2:508-12.

24. Lapidus PW. Operative treatment of metatarsus primus varus in hallux valgus. Surg Gynecol Obstet 1934;58:183-91.

25. Austin DW, Leventen EO. A new osteotomy for hallux valgus: a horizontally directed "V" displacement osteotomy of the metatarsal head for hallux valgus and primus varus. Clin Orthop Relat Res 1981;(157):25-30.

26. Mitchell CL, Fleming JL, Allen R, Glenney C, Sanford GA. Osteotomy-bunionectomy for hallux valgus. J Bone Joint Surg Am 1958;40-A(1):41-58; discussion 59-60.

27. Wilson JN. Oblique displacement osteotomy for hallux valgus. J Bone Joint Surg Br 1963;45:552-6.

28. Lindgren $U$, Turan I. A new operation for hallux valgus. Clin Orthop Relat Res 1983;(175):179-83.

29. LudloffK. Die Beseitigung des Hallux valgus durch die schräge plantar-dorsale Osteotomie des Metatarsus. Arch Klin Chir 1918;110:364-87.

30. Barouk LS. Scarf osteotomy of the first metatarsal in the treatment of hallux valgus. Foot Disease II 1991;1:35-48.

31. Borrelli AH, Weil LS. Modified scarf bunionectomy: our experience in more than one thousand cases. J Foot Surg 1991;30:609-12.

32. Akin $O$. The treatment of hallux valgus: A new operative procedure and its results. Med Sentinel 1925;33:678-9.

33. Saro C, Jensen I, Lindgren U, Felländer-Tsai L. Qualityof-life outcome after hallux valgus surgery. Qual Life Res 2007;16(5):731-8.

34. Thordarson D, Ebramzadeh E, Moorthy M, Lee J, Rudicel S. Correlation of hallux valgus surgical outcome with AOFAS forefoot score and radiological parameters. Foot Ankle Int 2005;26(2):122-7.
35. Monga $P$, Kumar A, Simons A. Outcome following surgery for hallux valgus: the patients' perspective. Foot Ankle Surg 2006;12:95-8.

36. Thomas TG. Medical litigation and the foot. The Foot 1991;1(1): 1 .

37. Rowley DI. Surgery to the great toe. J R Coll Surg Edinb 1991;36(5):335-6.

38. Gould N, Schneider W, Ashikaga T. Epidemiological survey of foot problems in the continental United States: 1978-1979. Foot Ankle 1980;1(1):8-10.

39. Coughlin MJ, Shurnas PS. Hallux rigidus. Grading and longterm results of operative treatment. J Bone Joint Surg Am 2003;85-A(11):2072-88.

40. Freed JB. The increasing recognition of medullary lysis, cortical osteophytic proliferation, and fragmentation of implanted silicone polymer implants. J Foot Ankle Surg 1993;32(2):171-9.

41. Granberry WM, Noble PC, Bishop JO, Tullos HS. Use of a hinged silicone prosthesis for replacement arthroplasty of the first metatarsophalangeal joint. J Bone Joint Surg Am 1991;73(10):1453-9.

42. Raikin SM, Ahmad J, Pour AE, Abidi N. Comparison of arthrodesis and metallic hemiarthroplasty of the hallux metatarsophalangeal joint. J Bone Joint Surg Am 2007;89(9):1979-85.

43. Erdil M, Elmadağ NM, Polat G, Tunçer N, Bilsel K, Uçan V, Erkoçak OF, Sen C. Comparison of arthrodesis, resurfacing hemiarthroplasty, and total joint replacement in the treatment of advanced hallux rigidus. J Foot Ankle Surg 2013;52(5):588-93. CrossRef

44. Moon JL, McGlamry MC. First metatarsophalangeal joint arthrodesis: current fixation options. Clin Podiatr Med Surg 2011;28(2):405-19, ix. doi: 10.1016/j.cpm.2011.02.002

45. Sullivan MR. Hallux rigidus: MTP implant arthroplasty. Foot Ankle Clin 2009;14(1):33-42. CrossRef

46. Townley CO, Taranow WS. A metallic hemiarthroplasty resurfacing prosthesis for the hallux metatarsophalangeal joint. Foot Ankle Int 1994;15(11):575-80.

47. Erdil M, Bilsel K, Imren Y, Mutlu S, Güler O, Gürkan V, Elmadağ NM, Tuncay I. Metatarsal head resurfacing hemiarthroplasty in the treatment of advanced stage hallux rigidus: outcomes in the short-term. Acta Orthop Traumatol Turc 2012;46(4):281-5.

48. Kline AJ, Hasselman CT. Metatarsal head resurfacing for advanced hallux rigidus. Foot Ankle Int 2013;34(5):716-25. CrossRef 